Biological Threats and Invasive Species Research Program

Supporting Data and Simulation of Hypothetical Bighiead Carp Egg and Larvae Development and Transport in the Ohío Bitver between Miarkland Locks and Dam and TMeAlpine Locks and Dam, Kentucky and lindiana, by use of the Fiturial Egg Drift Stmulator

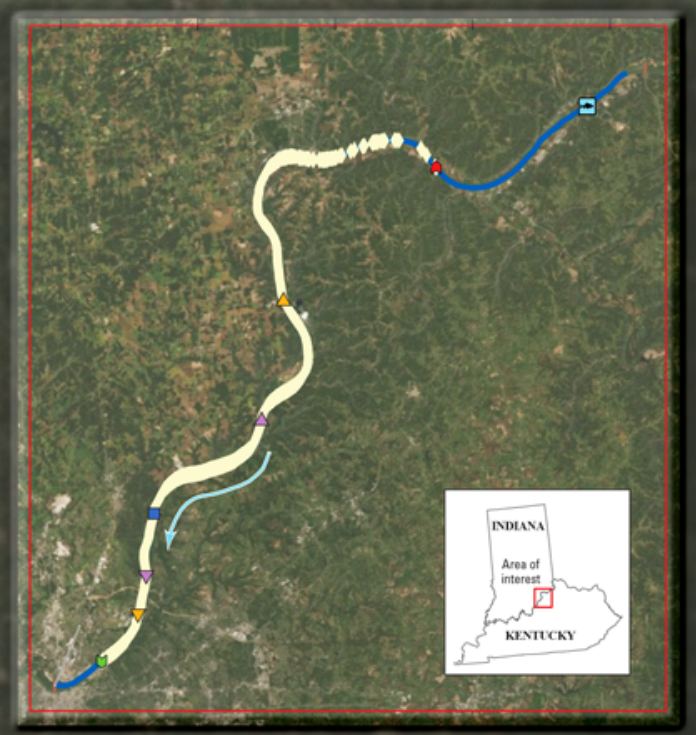

Scientific Investigations Report 2021-5005 
Cover. Modified versions of figure 12 of this report. 


\section{Supporting Data and Simulation of Hypothetical Bighead Carp Egg and Larvae Development and Transport in the Ohio River between Markland Locks and Dam and McAlpine Locks and Dam, Kentucky and Indiana, by use of the Fluvial Egg Drift Simulator}

By Chad J. Ostheimer, Justin A. Boldt, and Paul M. Buszka

Biological Threats and Invasive Species Research Program

Scientific Investigations Report 2021-5005 


\section{U.S. Geological Survey, Reston, Virginia: 2021}

For more information on the USGS - the Federal source for science about the Earth, its natural and living resources, natural hazards, and the environment—visit https://www.usgs.gov or call 1-888-ASK-USGS.

For an overview of USGS information products, including maps, imagery, and publications, visit https://store.usgs.gov/.

Any use of trade, firm, or product names is for descriptive purposes only and does not imply endorsement by the U.S. Government.

Although this information product, for the most part, is in the public domain, it also may contain copyrighted materials as noted in the text. Permission to reproduce copyrighted items must be secured from the copyright owner.

Suggested citation:

Ostheimer, C.J., Boldt, J.A., and Buszka, P.M., 2021, Supporting data and simulation of hypothetical bighead carp egg and larvae development and transport in the Ohio River between Markland Locks and Dam and McAlpine Locks and Dam, Kentucky and Indiana, by use of the Fluvial Egg Drift Simulator: U.S. Geological Survey Scientific Investigations Report 2021-5005, 30 p., https://doi.org/10.3133/sir20215005.

Associated data:

Boldt, J.A., 2021, Velocity and water-quality surveys in the Ohio River between Markland Locks and Dam and McAlpine Locks and Dam, Kentucky and Indiana, October 27-November 4, 2016, and June 26-29, 2017: U.S. Geological Survey data release, https://doi.org/10.5066/P9MOHEPU.

Ostheimer, C.J., 2021, Geospatial data and models for the simulation of hypothetical bighead carp egg and larvae development and transport in the Ohio River between Markland Locks and Dam and McAlpine Locks and Dam, Kentucky and Indiana, by use of the Fluvial Egg Drift Simulator: U.S. Geological Survey data release, https://doi.org/10.5066/P9JHLGZL.

ISSN 2328-0328 (online) 


\section{Contents}

Abstract

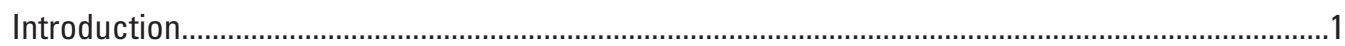

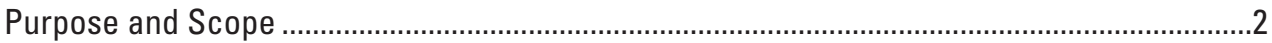

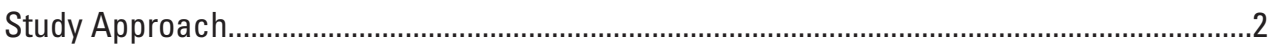

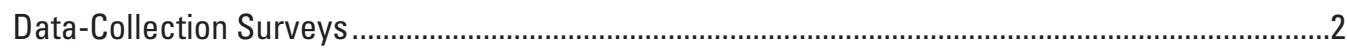

Velocity and Water-Quality Survey Methods ..........................................................................

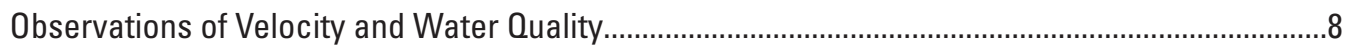

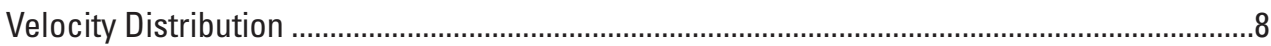

Water-Temperature Distribution ...........................................................................................

Distribution of Other Water-Quality Parameters .......................................................................

Real-Time Water-Quality Data at Markland Dam ………......................................................12

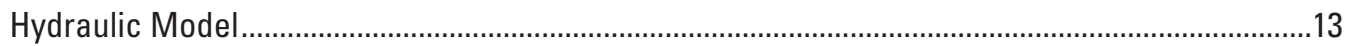

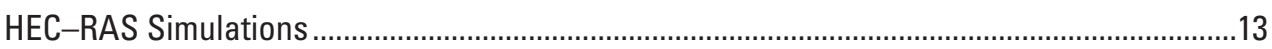

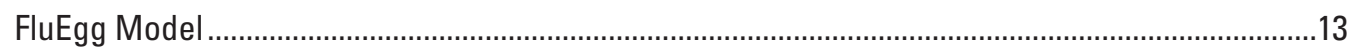

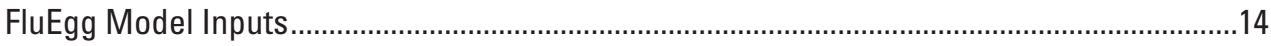

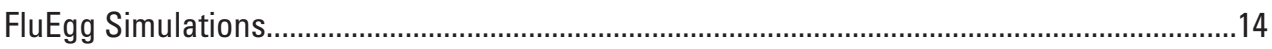

FluEgg Simulation Results ..............................................................................................

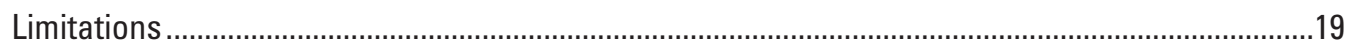

Summary

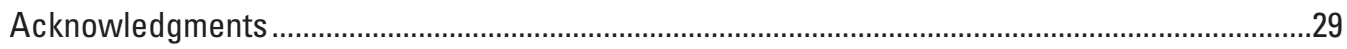

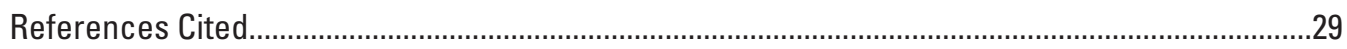

\section{Figures}

1. Map showing locations of Ohio River study reach, locks and dams, U.S. Geological Survey streamgages, and potential spawning locations ..........................3

2. Hydrographs showing streamflow from the U.S. Geological Survey streamgages Ohio River at Markland Dam near Warsaw, Kentucky and Ohio River at Water Tower at Louisville, Kentucky, and acoustic Doppler current profiler-measured streamflow during survey 1, 0ctober 27-November 4, 2016...............4

3. Hydrographs showing streamflow from the U.S. Geological Survey streamgages Ohio River at Markland Dam near Warsaw, Kentucky and Ohio River at Water Tower at Louisville, Kentucky, and acoustic Doppler current profiler-measured streamflow during survey 2, June 26-29, 2017.

4. Map showing the different methods of collecting water-quality data at the confluence of the Kentucky River with the Ohio River at Carrollton, Kentucky...

5. Plot showing mean cross-section velocity throughout the Ohio River study reach from Markland Locks and Dam to McAlpine Locks and Dam

6. Graph showing measurements of water temperature at 17 vertical profiles on October 27, 2016, and 25 vertical profiles on November 3, 2016, on the Ohio River between Markland Locks and Dam and McAlpine Locks and Dam.....

7. Boxplots showing water-quality parameters measured along vertical profiles on the Ohio River between Markland Locks and Dam and McAlpine Locks and Dam during survey 1 and survey 2 . 
8. Graph showing water temperature at the U.S. Geological Survey streamgage Ohio River at Markland Dam near Warsaw, Kentucky, 2016-2017.

9. Map showing the locations of the McAlpine Locks and Dam and U.S. Geological Survey streamgages. .15

10. Hydrograph showing the U.S. Geological Survey streamgage Ohio River at Water Tower at Louisville, Kentucky, for the period January 1, 2017 to January 1, 2018.

11. Map showing a simulated suspended egg plume at hatching time for eggs spawned at the outflow of the Ghent Generating Station on the Ohio River at a streamflow of 38,100 cubic feet per second and a water temperature of 30 degrees Celsius

12. Map showing a simulated suspended larvae plume at gas bladder inflation time for eggs spawned at the outflow from the Ghent Generating Station on the Ohio River at a streamflow of 38,100 cubic feet per second and a water temperature of 30 degrees Celsius.

13. Map showing a simulated suspended egg plume at hatching time for eggs spawned just downstream from the Markland Locks and Dam on the Ohio River at a streamflow of 38,100 cubic feet per second and a water temperature of 30 degrees Celsius

14. Map showing a simulated suspended larvae plume at gas bladder inflation time for eggs spawned just downstream from the Markland Locks and Dam on the Ohio River at a streamflow of 38,100 cubic feet per second and a water temperature of 30 degrees Celsius.

\section{Tables}

1. Summary statistics of water-quality parameters computed from near-surface measurements along cross sections and longitudinals on the Ohio River from Markland Locks and Dam to McAlpine Locks and Dam during survey 1 and survey 2 .

2. Monthly mean values of selected water-quality parameters from the water-quality sonde at U.S. Geological Survey streamgage Ohio River at Markland Dam near Warsaw, Kentucky, 2011-2020.

3. Comparison of recorded to simulated water-surface elevations at the U.S. Geological Survey streamgage Ohio River at Water Tower at Louisville, Kentucky

4. Quantiles of daily mean streamflow for June to September for the period of November 2013 to June 2020 at the U.S. Geological Survey streamgage Ohio River at Water Tower at Louisville, Kentucky.

5. Time to egg hatching and gas bladder inflation stages for bighead carp at various water temperatures

6. Mean percentages of egg hatching, egg mortality, larvae reaching gas bladder inflation stage, and embryo survival on the Ohio River between Markland Locks and Dam and McAlpine Locks and Dam, determined by use of the Fluvial Egg Drift Simulator

7. Percentages of egg hatching, egg mortality, larvae reaching gas bladder inflation stage, and embryo survival, and quantile distances to egg hatching and gas bladder inflation stage downstream from potential spawning location on the Ohio River between Markland Locks and Dam and McAlpine Locks and Dam, determined by use of the Fluvial Egg Drift Simulator. 


\section{Conversion Factors}

U.S. customary units to International System of Units

\begin{tabular}{|c|c|c|}
\hline Multiply & By & To obtain \\
\hline \multicolumn{3}{|c|}{ Length } \\
\hline foot $(\mathrm{ft})$ & 0.3048 & meter $(\mathrm{m})$ \\
\hline mile (mi) & 1.609 & kilometer (km) \\
\hline \multicolumn{3}{|c|}{ Area } \\
\hline square mile $\left(\mathrm{mi}^{2}\right)$ & 2.590 & square kilometer $\left(\mathrm{km}^{2}\right)$ \\
\hline \multicolumn{3}{|c|}{ Flow rate } \\
\hline cubic foot per second ( $\left.\mathrm{ft}^{3} / \mathrm{s}\right)$ & 0.02832 & cubic meter per second $\left(\mathrm{m}^{3} / \mathrm{s}\right)$ \\
\hline
\end{tabular}

International System of Units to U.S. customary units

\begin{tabular}{lll}
\hline \multicolumn{1}{c}{ Multiply } & By & \multicolumn{1}{c}{ To obtain } \\
\hline meter $(\mathrm{m})$ & Length & \\
kilometer $(\mathrm{km})$ & 3.2808 & foot $(\mathrm{ft})$ \\
\hline & 0.621 & mile $(\mathrm{mi})$ \\
\hline centimeter per second $(\mathrm{cm} / \mathrm{s})$ & Velocity & \\
\hline
\end{tabular}

Temperature in degrees Celsius $\left({ }^{\circ} \mathrm{C}\right)$ may be converted to degrees Fahrenheit $\left({ }^{\circ} \mathrm{F}\right)$ as follows:

$$
{ }^{\circ} \mathrm{F}=\left(1.8 \mathrm{x}^{\circ} \mathrm{C}\right)+32 \text {. }
$$

Specific conductance is given in microsiemens per centimeter at 25 degrees Celsius $(\mu \mathrm{S} / \mathrm{cm})$.

Concentrations of chemical constituents in water are given in milligrams per liter $(\mathrm{mg} / \mathrm{L})$ or relative fluorescence units (RFU).

\section{Datum}

Vertical coordinate information is referenced to (1) stage, the height above an arbitrary datum established at a streamgage, and (2) elevation, the height above the North American Vertical Datum of 1988 (NAVD 88).

Horizontal coordinate information is referenced to the North American Datum of 1983 (NAD 83). 


\section{Abbreviations}

$\begin{array}{ll}\text { ADCP } & \text { acoustic Doppler current profiler } \\ \text { FluEgg } & \text { Fluvial Egg Drift Simulator } \\ \text { GBI } & \text { gas bladder inflation } \\ \text { HEC-RAS } & \text { Hydrologic Engineering Center-River Analysis System } \\ \text { OMD } & \text { outside model domain } \\ \text { RFU } & \text { relative fluorescence units } \\ \text { USGS } & \text { U.S. Geological Survey }\end{array}$




\title{
Supporting Data and Simulation of Hypothetical Bighead Carp Egg and Larvae Development and Transport in the Ohio River between Markland Locks and Dam and McAlpine Locks and Dam, Kentucky and Indiana, by use of the Fluvial Egg Drift Simulator
}

\author{
By Chad J. Ostheimer, Justin A. Boldt, and Paul M. Buszka
}

\begin{abstract}
Data collection, along with hydraulic and fluvial egg transport modeling, was completed along a 70.9-mile reach of the Ohio River between Markland Locks and Dam and McAlpine Locks and Dam in Kentucky and Indiana. Water-quality data collected in this reach included surface measurements and vertical profiles of water temperature, specific conductance, $\mathrm{pH}$, dissolved oxygen, turbidity, relative chlorophyll, and relative phycocyanin. Data were collected during two surveys: October 27-November 4, 2016, and June 26-29, 2017. Streamflow and velocity data were collected simultaneously with the water-quality data at cross sections and along longitudinal lines (corresponding to the water-quality surface measurements) and at selected stationary locations (corresponding to the water-quality vertical profiles). The data were collected to understand variability of flow and water-quality conditions relative to simulated reaches of the Ohio River and to aid in identifying parts of the reach that may provide conditions favorable to spawning and recruitment habitat for Hypophthalmichthys nobilis (bighead carp).

A copy of an existing step-backwater model of Ohio River flows was obtained from the National Weather Service and used to simulate hydraulic conditions for four different streamflows. Streamflows were selected to represent typical conditions ranging from a high-streamflow event to a seasonal dry-weather event, with two streamflows between these extremes for this reach of the Ohio River. Outputs from the hydraulic model, a range of five water temperatures observed in water-quality data, and four potential spawning locations were used as input to the Fluvial Egg Drift Simulator to simulate the extents and quantile positions of developing bighead carp, from egg hatching to the gas bladder inflation stage, under each scenario. A total of 80 simulations were run.

Results from the Fluvial Egg Drift Simulator scenarios (which include only the hydraulic influences on survival that result from settling, irrespective of mortality from other
\end{abstract}

physical or biological factors such as excess turbulence, fertilization failure, predation, or starvation) indicate that most eggs will hatch, about half will die, and a quarter of the surviving larvae will reach the gas bladder inflation stage within the model reach. The overall mean percentage of embryos surviving to the gas bladder inflation stage was 13.1 percent. Individual simulations have embryo survival percentages as high as 49.1 percent. The highest embryo survival percentages occurred for eggs spawned at a streamflow of 38,100 cubic feet per second and water temperatures of 24 to 30 degrees Celsius. Conversely, embryo survival percentages were lowest for the lowest and highest streamflows regardless of water temperature or spawn location. Under low water temperature and high-streamflow conditions, some of the eggs did not hatch nor did the larvae reach the gas bladder inflation stage until passing beyond the downstream model domain. Although the final quantile positions of the eggs and larvae beyond the downstream model domain are unknown, the outcomes still provide useful information about conditions favorable to spawning and recruitment habitat for bighead carp in the Ohio River.

\section{Introduction}

Bigheaded carps, including bighead and silver carp, are native to China and are commonly referred to as Asian carp in North America (Chapman, 2010). The bigheaded carps Hypophthalmichthys nobilis (bighead carp) and Hypophthalmichthys molitrix (silver carp) have been expanding in abundance and range into the Ohio River Basin (Ohio River Fisheries Management Team, 2014). Bigheaded carps are aquatic invasive species that are recognized as having the potential for creating adverse environmental and economic effects. Although several projects involving the simulation of Asian carp egg and larvae development and transport have been completed on streams 
within the Great Lakes Basin and streams connecting the Great Lakes to the Mississippi River Basin (Garcia and others, 2013, 2015; Murphy and others, 2016; Zhu and others, 2018), little work has been completed on large rivers such as the Ohio River and its tributaries. As of 2014, spawning populations of Hypophthalmichthys nobilis (bighead carp) were documented in the reaches of the Ohio River downstream from McAlpine Locks and Dam. Also, in 2014, a large population of bighead carp characteristic of an invasion front was described for the river segment between Markland Locks and Dam and McAlpine Locks and Dam (hereafter referred to as Markland Dam and McAlpine Dam) in Kentucky and Indiana (Ohio River Fisheries Management Team, 2014). Simulation of bighead carp egg and larvae development and transport from the invasion front reaches, and in particular between Markland Dam and McAlpine Dam, is needed to understand whether bighead carp populations in the spawning reach below McAlpine Dam can originate from the populations in an invasion front reach.

This study adapted developments from prior U.S. Geological Survey (USGS) work to evaluate spawning habitat and understand controls on spawning and recruitment of bighead carp within the Ohio River Basin. This study approach aligns with goals of the Ohio River Fisheries Management Team and its member Federal and State agencies, including the USGS, that are directed to improve capabilities and guide efforts to detect early stages of invasion and spawning of bighead carp populations and to ultimately reduce and control bighead carp populations.

\section{Purpose and Scope}

The purpose of this report is to describe the methods and results of data collection and hydraulic analyses for a 70.9-mile (114.1 kilometer) reach of the Ohio River between Markland and McAlpine Dams in Kentucky and Indiana (fig. 1). Water-quality data collected in this reach included surface measurements and vertical profiles of water temperature, specific conductance, $\mathrm{pH}$, dissolved oxygen, turbidity, relative chlorophyll, and relative phycocyanin. Waterquality and flow data were collected during two surveys: October 27-November 4, 2016, and June 26-29, 2017. The data and analyses include (1) collection of acoustic Doppler current profiler (ADCP) measurements of stream velocities and streamflow and water-quality profiles at selected crosssection, longitudinal, and stationary locations along the study reach; (2) steady-state hydraulic modeling of the study reach; and (3) simulation of fluvial egg transport of bighead carp eggs along the study reach for various spawning scenarios using the Fluvial Egg Drift Simulator (FluEgg) model (Garcia and others, 2013). The water-quality and flow data were used to characterize this section of the Ohio River and evaluate and confirm conditions assumed in the hydraulic and FluEgg simulations.

\section{Study Approach}

Tasks specific to the development of the egg dispersion maps described in this section include processes used to (1) collect ADCP measurements of stream velocities and streamflow and water-quality profiles at selected cross-section, longitudinal, and stationary locations along the study reach; (2) procure a copy of the Ohio River Community Model from the National Weather Service (Adams and others, 2010); (3) modify the Ohio River Community Model to simulate flow velocities and depths; (4) use the FluEgg model to simulate fluvial egg transport along the study reach for various spawning scenarios; and (5) produce maps showing the final locations of the simulated egg plumes when they hatch, develop into a larval stage, and when the larvae have reached the gas bladder inflation stage. Characteristics of the models and their use are described later in this report.

\section{Data-Collection Surveys}

Two separate data-collection surveys (one during normal, dry-weather streamflow and one during higher streamflow) were made along the reach of the Ohio River from Markland Dam to McAlpine Dam (approximately 71 river miles, fig. 1). The surveys were done to aid in identifying parts of this river reach that may provide spawning and recruitment habitat for bighead carp and to evaluate conditions used in the hydraulic and fluvial egg transport models.

The first survey (survey 1) was conducted over 7 days during October 27-November 4, 2016 (on weekdays during daylight hours), during a period of relatively stable, dryweather streamflow in the Ohio River. Hydrographs from the USGS streamgages Ohio River at Markland Dam near Warsaw, Kentucky (station number 03277200; U.S. Geological Survey, 2019a) and Ohio River at Water Tower at Louisville, Kentucky (station number 03292494; U.S. Geological Survey, 2019c) (hereafter referred to as the Markland and Water Tower streamgages, respectively) during the period around survey 1 are shown in figure 2 along with mean streamflow values as measured by the ADCP on each day. Although standard moving boat ADCP measurement protocols were followed to the extent necessary (Mueller and others, 2013), the objective of the survey was not to measure streamflow, so techniques varied as needed. The ADCP-measured streamflow values are provided to confirm streamflow at locations between the Markland and Water Tower streamgages, but they are considered estimates for several reasons, including the use of more than one cross-section location, only one transect was measured at each cross section, and the length of time between the start and end of the survey on each day. In general, there is agreement between the ADCP-measured streamflow and the streamgage records, especially when considering what section of the reach was being measured each day. For example, the 


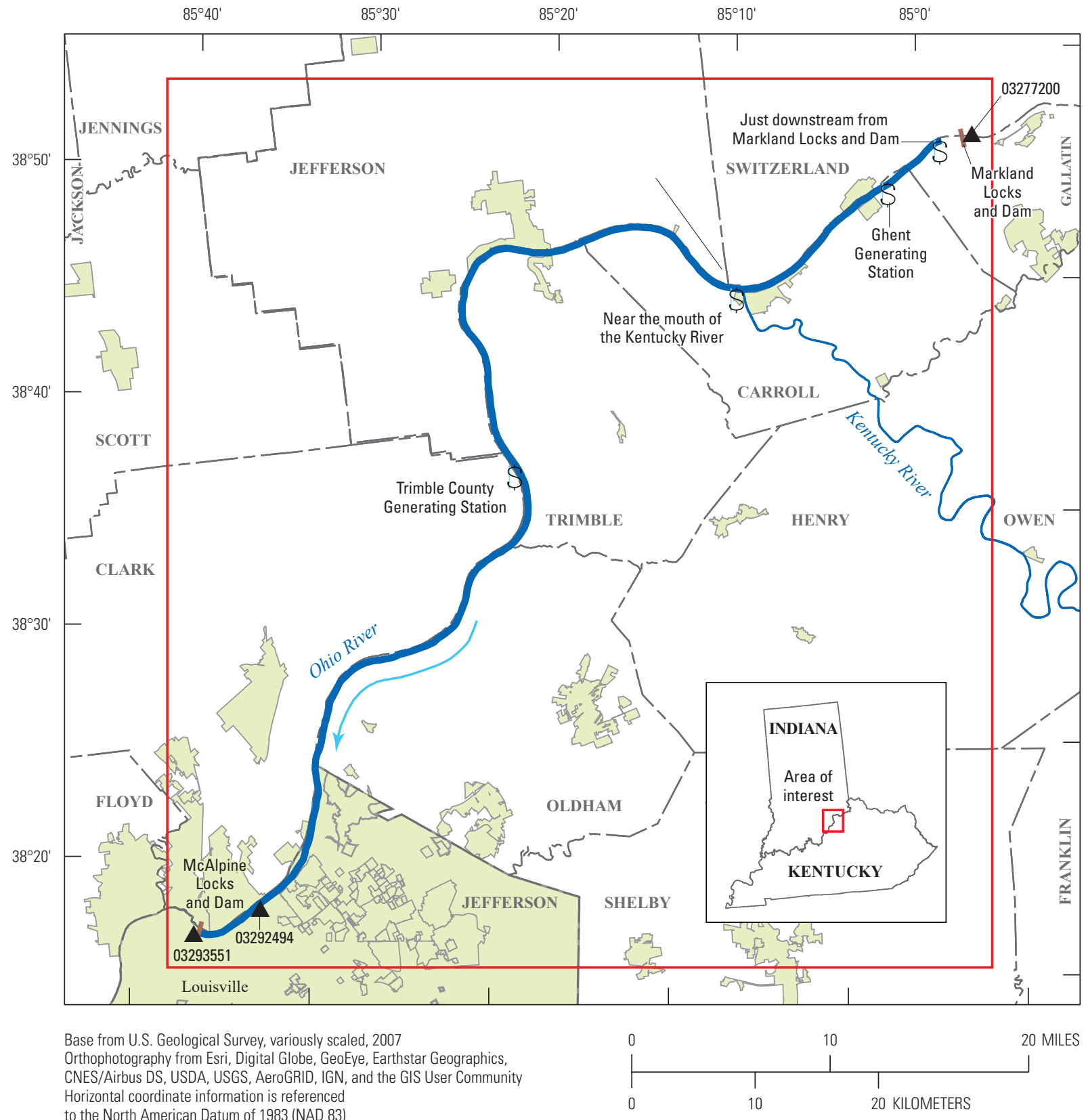

to the North American Datum of 1983 (NAD 83)

\section{EXPLANATION}

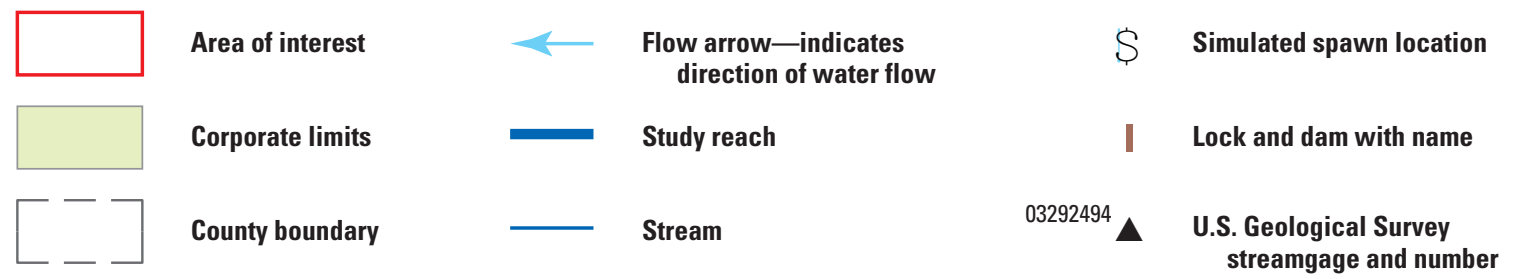

Figure 1. Map showing locations of Ohio River study reach, locks and dams, U.S. Geological Survey streamgages, and potential spawning locations. 


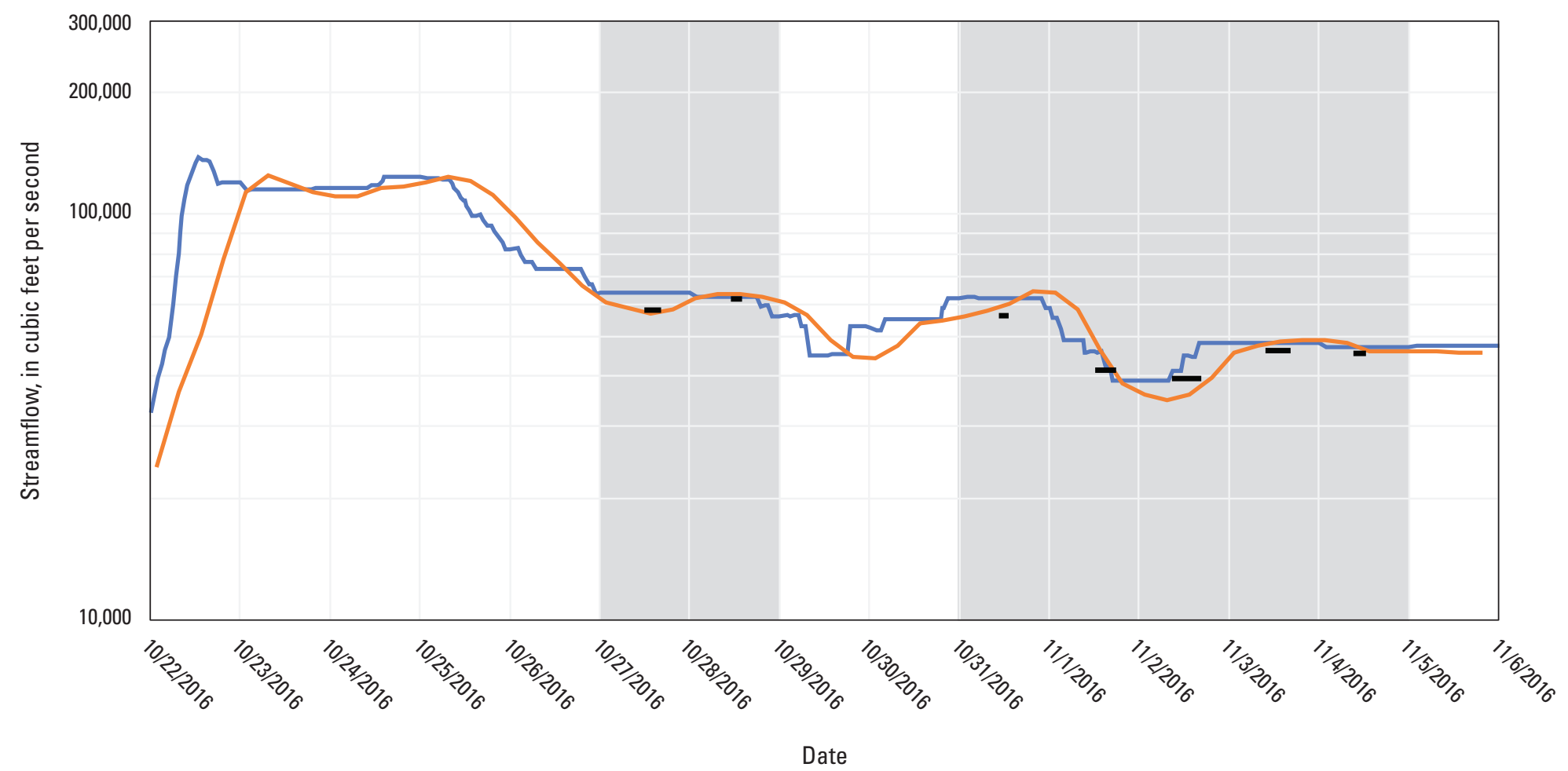

EXPLANATION

Survey dates: October 27 to November 4, 2016

Markland streamgage (USGS 03277200)

Water Tower streamgage (USGS 03292494)

Acoustic Doppler current profiler measurements

Figure 2. Hydrographs of streamflow from the U.S. Geological Survey streamgages Ohio River at Markland Dam near Warsaw, Kentucky (station number 03277200;

U.S. Geological Survey, 2019a) and Ohio River at Water Tower at Louisville, Kentucky (station number 03292494; U.S. Geological Survey, 2019c), and acoustic Doppler current profiler-measured streamflow during survey 1, October 27-November 4, 2016. 
cross sections measured on the first day (October 27, 2016) were all near the downstream end of the reach where the Water Tower streamgage is located, so it makes sense that the mean ADCP-measured streamflow for the first day agrees well with the Water Tower streamgage reading (fig. 2).

The second survey (survey 2) was conducted over four days during June 26-29, 2017 (again, during daylight hours), during a period of higher streamflow in the Ohio River due to a precipitation event from post-Tropical Storm Cindy. The second survey started just after the peak flow from this event and continued during the falling limb of the hydrograph. Hydrographs from the Markland and the Water Tower streamgages during the period around survey 2 are shown in figure 3 along with mean streamflow values as measured by the ADCP on each day. Because of the rapid decrease in flow on June 28 and 29, 2017, the mean streamflows for these two days were each split into two groupings (approximately a morning grouping and an afternoon grouping) to better capture the change in flow. Again, the ADCP-measured streamflow values are provided to confirm streamflow at locations between the Markland and Water Tower streamgages, but they are considered estimates for the reasons stated previously. As in survey 1 , there is agreement in survey 2 between the ADCPmeasured streamflow and the streamgage records, especially when considering what section of the reach was being measured each day. For example, the cross sections measured on the second day (June 27, 2017) were all near the upstream end of the reach where the Markland streamgage is located, so it makes sense that the mean ADCP-measured streamflow for the second day agrees well with the Markland streamgage reading (fig. 3).

\section{Velocity and Water-Quality Survey Methods}

Data were collected to represent variability of flow and water-quality conditions along the longitudinal (streamwise) direction, cross-river transects, and vertically (throughout the water column) and included ADCP-based velocity and sonde-based water-quality measurements of water temperature, specific conductance, $\mathrm{pH}$, dissolved oxygen, turbidity, relative chlorophyll, and relative phycocyanin. All data were collected from a manned boat outfitted with a Global Positioning System and navigation software. The velocity data were collected with a Teledyne RD Instruments 1,200 kilohertz Rio Grande ADCP mounted to the side of the boat on a rigid aluminum pole. The water-quality data were collected with a Yellow Springs Instrument EXO2 multiparameter sonde (survey 1) and an OTT Hydrolab MS5 multiparameter sonde (survey 2) either towed (for surface measurements) or lowered (for depth measurements) from the side of the boat. For survey, the velocity and water-quality data were collected (1) along 75 cross sections, typically spaced 1 river mile apart; (2) along longitudinal profiles between cross sections at approximately the centerline of the river; and (3) at
138 stationary locations (vertical profiles of water-quality parameters), typically 3 equal-width-increment stations at every other cross section and 5 equal-discharge-increment stations in areas of interest where velocity and/or water-quality parameters may have localized differences. These areas of interest were locations near the two dams (Markland and McAlpine): at the mouth of the Kentucky River (its confluence with the Ohio River) and near power-generating stations adjacent to the Ohio River (fig. 1). For both surveys, the cross section and longitudinal water-quality profile data were logged continuously at 5-second intervals, and for survey 1 , the vertical water-quality profiles were logged as discrete point samples at 2-foot (ft) increments from the surface to $10 \mathrm{ft}$ depth and at 5-ft increments from 10 to $50 \mathrm{ft}$ (the maximum cable length). Because the sonde did not have a depth sensor, these depth increments were marked on the cable ahead of time. Although no calculation was done to account for the cable angle, minimization was attempted by attaching a weight to the bottom of the water-quality sonde and allowing the boat to drift with the flow during each vertical profile. The total depth at each water-quality vertical was determined from the ADCP, which was collecting a stationary velocity profile simultaneously with the water-quality measurements. The total depth was communicated to the person lowering the sonde to give them an idea of when to expect the river bottom. The maximum depth measured by the ADCP at the locations of the water-quality verticals during survey 1 was $49.6 \mathrm{ft}$. Similar procedures were followed for survey 2 , except the number of cross sections and stationary locations were reduced to 69 and 106, respectively. The method of collecting the vertical water-quality profiles was also changed for survey 2 such that the sonde was slowly lowered at approximately 1-2 feet per second $(\mathrm{ft} / \mathrm{s})$ from the surface to either the riverbed or the maximum cable length $(50 \mathrm{ft})$ while logging at a 1 -second interval. The maximum depth measured by the ADCP at the locations of the water-quality verticals during survey 2 was $52.9 \mathrm{ft}$.

The different methods of collecting water-quality data (cross sections, longitudinals, and verticals) are shown as an example in figure 4 for the confluence of the Kentucky River with the Ohio River at Carrollton, Kentucky. Each red or orange dot is a surface water-quality measurement (all parameters) at the 5-second interval. Because this location was an area of interest (river confluence), an extra cross section (number 378) was added just downstream from the mouth of the Kentucky River (fig. 4). Additionally, the two cross sections immediately downstream from the confluence (numbers 378 and 377) were sampled in more detail (using a five-vertical equal-discharge-increment method as opposed to using a three-vertical equal-width-increment method) to better capture the mixing dynamics associated with the confluence (fig. 4). The velocity and water-quality data are available for download through a data release at https://doi.org/10.5066/P9MQHEPU (Boldt, 2021). 


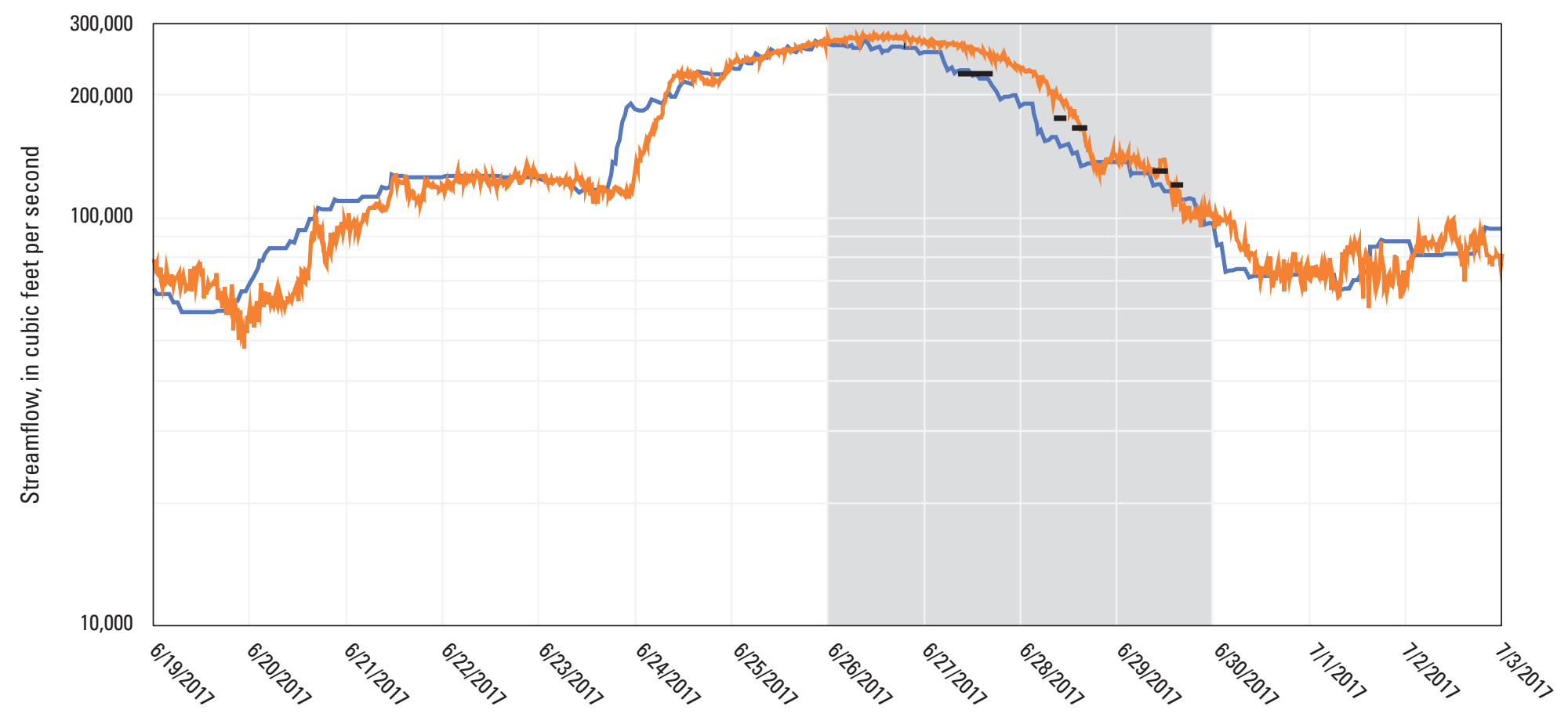

Date

\title{
EXPLANATION
}

\author{
Survey dates: June 26—29, 2017
}

\section{Markland streamgage (USGS 03277200)}

\section{Water Tower streamgage (USGS 03292494)}

Acoustic Doppler current profiler measurements

Figure 3. Hydrographs of streamflow from the U.S. Geological Survey streamgages Ohio River at Markland Dam near Warsaw, Kentucky (station number 03277200;

U.S. Geological Survey, 2019a) and Ohio River at Water Tower at Louisville, Kentucky (station number 03292494; U.S. Geological Survey, 2019c), and acoustic Doppler current profiler-measured streamflow during survey 2, June 26-29, 2017. 


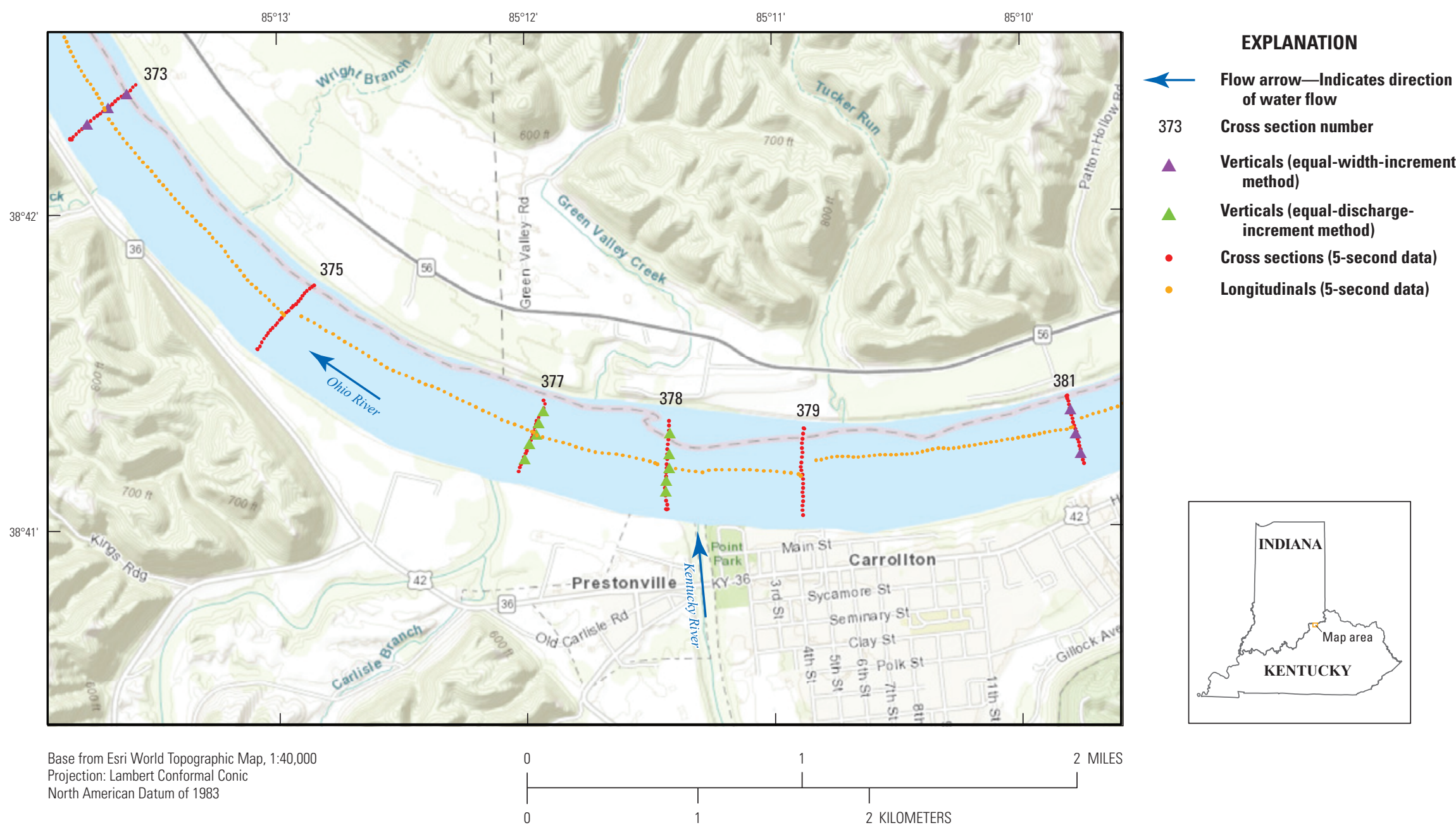

Figure 4. Map showing the different methods of collecting water-quality data at the confluence of the Kentucky River with the Ohio River at Carrollton, Kentucky. 


\section{Observations of Velocity and Water Quality}

Observations of velocity and water quality as they relate to bighead carp spawning habitat and fluvial egg drift modeling are described below. The field data collected in this study were used to assess the validity of assumptions made by the FluEgg model about the input velocity and waterquality values.

\section{Velocity Distribution}

The velocity inputs to the FluEgg model include the three-dimensional components of water velocity and shear velocity, which can be obtained in several different ways. In this study, the velocity inputs to the FluEgg model were obtained from a one-dimensional hydraulic model, so the field data can be used to validate the output from the hydraulic model and to confirm the assumptions made by the FluEgg model.
Mean streamwise velocities during survey 1, as computed from streamflow divided by area at 75 different cross sections, ranged from 0.75 to $2.34 \mathrm{ft} / \mathrm{s}$. The overall range in velocities, which are generally higher at the upstream end of the reach and lower at the downstream end of the reach, is due primarily to the effect of the two dams within this reach, but variation between cross sections is due to the natural differences in cross-section shape. Because the streamflow during survey 1 was relatively stable, the mean velocity at each cross section can be plotted as a function of streamwise distance to show a downward trend in mean velocity from Markland Dam to McAlpine Dam (fig. 5). The mean velocities decreased rapidly over the first 20 miles downstream from Markland Dam, and then decreased at a much slower rate over the remaining distance of the reach until McAlpine Dam. The decrease in mean velocities is important for bighead carp lifecycles because they are known to spawn in areas of higher velocity and turbulence, and the area just downstream from Markland Dam can provide that type of flow condition. The Kentucky River confluence with the Ohio River is located 14 miles downstream from Markland Dam. The mean velocity drops slightly at that point due to a deeper and slightly wider channel, and thus a

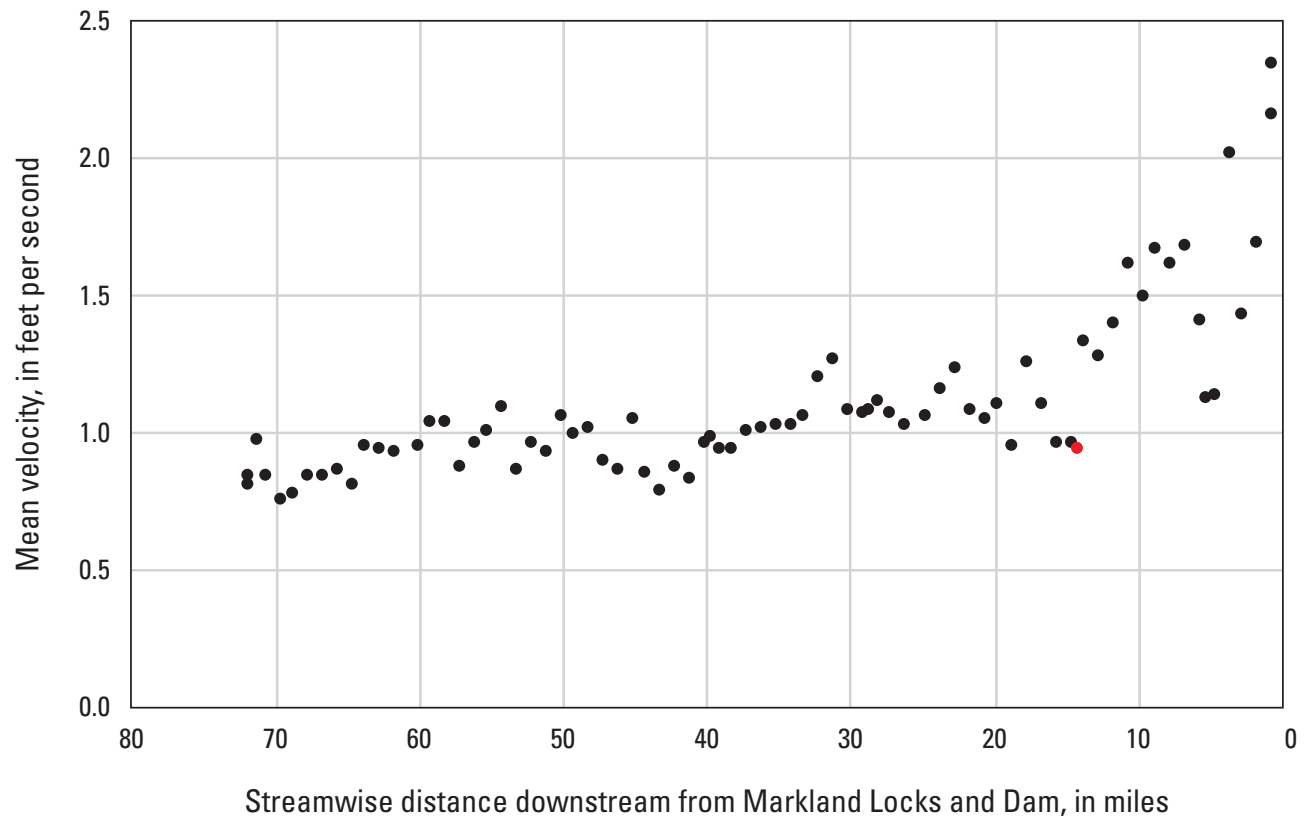

EXPLANATION

- Measurements of mean velocity

- Kentucky River confluence

Figure 5. Plot of mean cross-section velocity throughout the Ohio River study reach from Markland Locks and Dam to McAlpine Locks and Dam. 
larger cross-sectional area, downstream from the confluence as compared to upstream from the confluence. Mean streamwise velocities during survey 2 , as computed from streamflow divided by area at 69 different cross sections, ranged from 1.51 to $4.58 \mathrm{ft} / \mathrm{s}$. In general, the mean velocities decreased from Markland Dam to McAlpine Dam; however, survey 2 was conducted from upstream to downstream during the falling limb of a hydrograph, so the overall range and downward trend in mean velocities is due primarily to the decreasing streamflow over the survey period. During both surveys, the Kentucky River streamflow was about 2-3 percent of the Ohio River streamflow, so it was not a substantial source of inflow. However, there are times when streamflow in the Kentucky River is large, which is why this location was an area of interest and a potential spawning location.

The shear velocity is a critical parameter to calculate because it determines whether Asian carp eggs will remain in suspension or settle out of the water column where it is thought they would perish (Kolar and others, 2007). A particle (or Asian carp egg) will remain in suspension only when the turbulent vertical-velocity fluctuations in the flow overcome the settling velocity of the particle (Bagnold, 1966). The shear velocity at each vertical location was estimated by averaging the stationary ADCP data (mean flow velocity distribution) and fitting a logarithmic law of the wall profile (Sime and others, 2007; Garcia, 2008). For survey 1, the mean shear velocity within the entire reach was 2.30 centimeters per second $(\mathrm{cm} / \mathrm{s})$, and for survey 2 , the mean shear velocity within the entire reach was $6.27 \mathrm{~cm} / \mathrm{s}$. According to data published in Murphy and Jackson (2013), the settling velocity of bighead carp eggs in the period 0 to 2 hours after fertilization is about $2.1 \mathrm{~cm} / \mathrm{s}$, and the settling velocity decreases to about $0.8 \mathrm{~cm} / \mathrm{s}$ about 20 hours after fertilization. There is likely little change in the settling velocity in the period from 20 hours after fertilization to until the egg hatches. Therefore, the reach-averaged (arithmetic mean) shear velocity values from the field data indicate that this part of the Ohio River is generally capable of supporting the development and transport of bighead carp eggs during the range of flow conditions experienced during the two surveys.

\section{Water-Temperature Distribution}

The FluEgg model uses water temperature when simulating fluvial egg transport of bighead carp eggs. A known limitation of the FluEgg model is that a single value of water temperature is used to represent the entire reach (Garcia and others, 2013). Daily fluctuations in water temperature can be expected due to diurnal patterns, but another aspect of water-temperature differences that the data surveys can help identify is the spatial variability (both horizontally and vertically) in the river. Tributary confluences and streamflows from power-generating stations along the river were identified as possible sources of warmer or colder water, and one objective of the data collection was to identify how far downstream and laterally this water, of a potentially different temperature, persisted in the Ohio River. The simulated bighead carp eggs are also able to drift vertically in the FluEgg model, so another objective was to determine how water temperature varied throughout the water column. Water temperature influences how fast the bighead carp eggs develop, so it is important to understand whether the use of a single value for water temperature in the FluEgg model is a major limitation.

Results of the surveys indicated water temperatures on each day of the two surveys were nearly the same from the water surface to the river bottom. For each vertical profile, numerous point samples were collected throughout the depth, so the standard deviation of water temperature can be computed for each vertical profile to describe the variability. For survey 1 , the mean standard deviation of water temperature from the vertical profiles was 0.02 degree $\left(^{\circ}\right)$ Celsius (C) with a maximum standard deviation of $0.33^{\circ} \mathrm{C}$. For survey 2 , the mean standard deviation of water temperature from the vertical profiles was $0.05{ }^{\circ} \mathrm{C}$, with a maximum standard deviation of $0.67^{\circ} \mathrm{C}$. Water-temperature measurements from two different survey days (17 verticals on October 27, 2016, and 25 verticals on November 3, 2016) show the consistency of values throughout the vertical profile (fig. 6). Each data point represents a discrete point sample at a specified depth, and the points from the same vertical profile are connected by a line. The ranges of water temperatures within each day were caused by the diurnal cycle, and the differences in water temperatures between the two days was caused by changes in the ambient weather conditions. The main takeaway from this plot is that each line is nearly vertical, meaning that the water temperatures were nearly the same from the water surface to the river bottom. Thus, the use of a single value for water temperature in the FluEgg model is a reasonable assumption based on the data collected during the two surveys. One important implication of this finding is that the existing water-temperature data available in this reach (which comes from measurements near the surface at the Markland and Water Tower streamgages) can be used to characterize representative values of water temperatures in the river over time.

\section{Distribution of Other Water-Quality Parameters}

Vertical profiles of other water-quality parameters related to habitat and flow in the surveyed reach, including specific conductance, $\mathrm{pH}$, dissolved oxygen, turbidity, relative phycocyanin, and relative chlorophyll, were examined for variability within the water column (fig. 7). Although these properties are not represented in the FluEgg model, they are descriptive of conditions related to flow circulation and overall phytoplankton productivity that relate to habitat and food availability for bighead carp within this reach of an invasive front. Whereas figure 6 showed individual point measurement at specific depths during two different days, all the vertical profile data are now summarized with boxplots in figure 7 , which are 


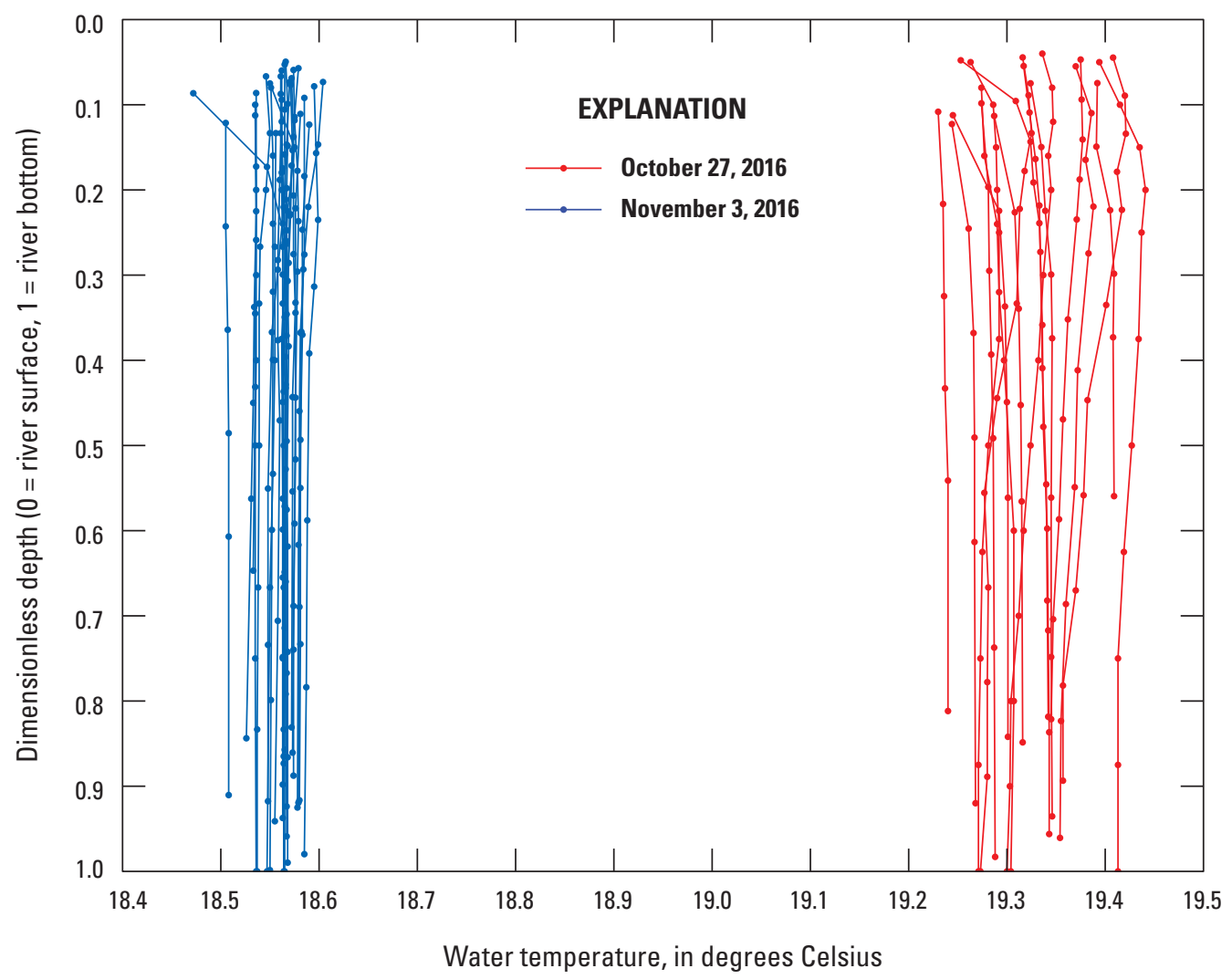

Figure 6. Graph showing measurements of water temperature at 17 vertical profiles on October 27, 2016, and 25 vertical profiles on November 3, 2016, on the Ohio River between Markland Locks and Dam and McAlpine Locks and Dam.

categorized into three groups in the vertical (top third, middle third, and bottom third of the water column) and divided between survey 1 and survey 2 .

Although water temperature was discussed in the previous section, the plots in figure 7 encompass data from all days of the two surveys. In both surveys, median water temperature was nearly the same throughout the water column. Specific conductance and $\mathrm{pH}$ values were generally constant throughout the vertical profiles as well, similar to what was found for water temperature.

During both surveys, median dissolved oxygen concentrations were highest at the top third of the water column (near the water surface) and showed a decline during survey 2 from the middle third to the bottom third of the water column (near the river bottom). For survey 1, dissolved oxygen concentrations near the river bottom ranged from 7.8 to 9.2 milligrams per liter $(\mathrm{mg} / \mathrm{L})$; dissolved oxygen concentrations along each vertical near the water surface ranged from 7.8 to $10 \mathrm{mg} / \mathrm{L}$. A similar distribution was observed in survey 2 , with dissolved oxygen concentrations near the river bottom ranging from 6.4 to $8.1 \mathrm{mg} / \mathrm{L}$, and dissolved oxygen concentrations near the water surface ranging from 6.5 to $9.6 \mathrm{mg} / \mathrm{L}$. Although not a comprehensive analysis, these data indicate relatively aerobic conditions in the surveyed parts of the reach that were not limiting the viability of bighead carp.

Turbidity, phycocyanin, and chlorophyll were measured only during survey 1 . Turbidity generally increased with water depth. Probe-measured relative phycocyanin concentrations, indicative of blue-green algae (cyanobacteria) abundance and therefore a representation of productivity and food abundance for bighead carp (Chapman, 2010), were highest near the water surface. Phycocyanin fluorescence was generally similar in the lower two-thirds of the verticals and typically ranged in that interval from about 0.50 to 0.70 relative fluorescence units (RFU). Phycocyanin concentration within the top third of the vertical sections (closest to the water surface) ranged from about $0.50 \mathrm{RFU}$ along well-mixed profiles to $2 \mathrm{RFU}$ along other profiles. In contrast to phycocyanin, chlorophyll measurements were relatively consistent among the three vertical groups. Although not a comprehensive analysis, these data indicate the largest productivity in the sampled reach is nearer to the water surface where light penetration and photosynthetic activity are typically greatest. 
Survey 1: October 27-November 4, 2016
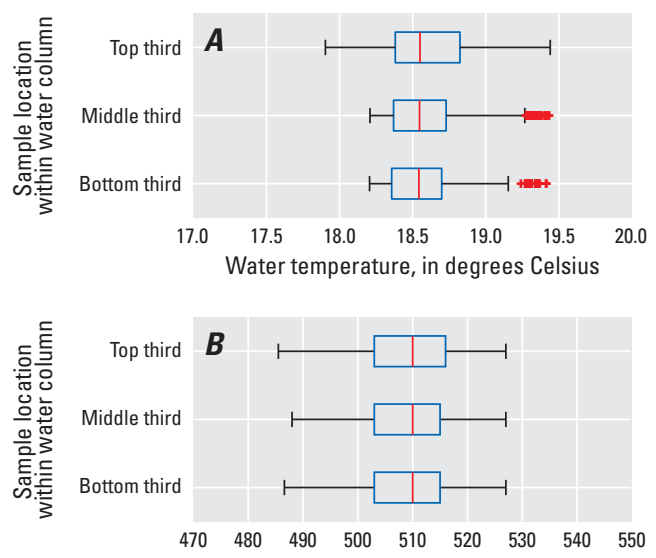

Specific conductance, in microsiemens per centimeter
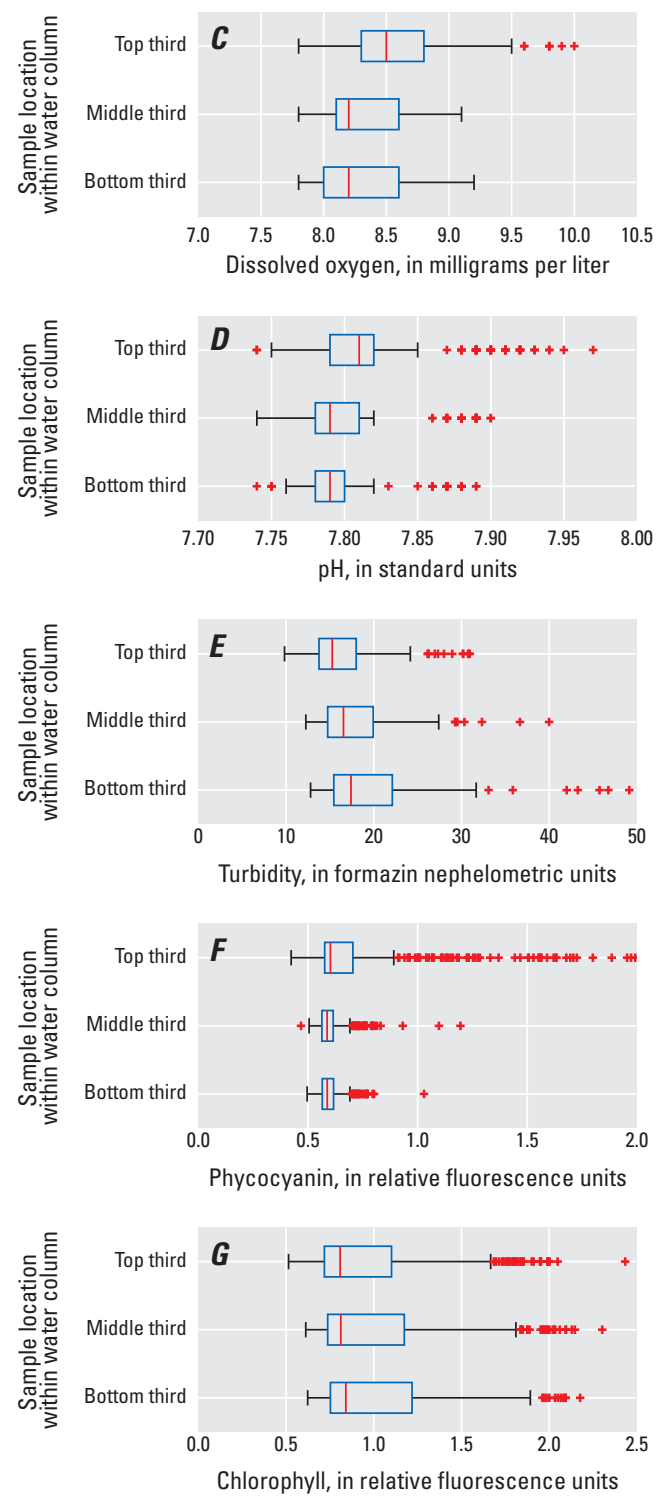

Survey 2: June 26-29, 2017
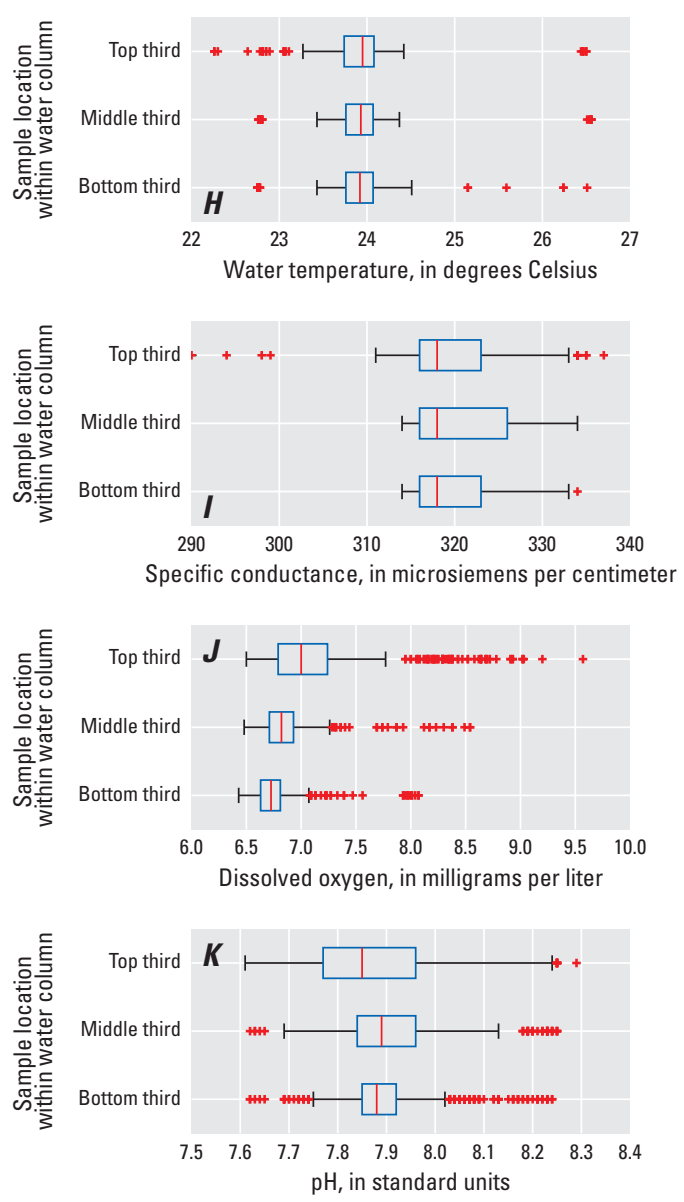

\section{EXPLANATION}

[IR, interquartile range $=075-025]$

Outlier (points greater than $075+1.5^{*} \mid R$ )

Maximum value less than or equal to $075+1.5 * I R$

75th percentile (075)

Median

25th percentile (025)

Minimum value greater than or equal to $025-1.5 * I R$

Outlier (points less than 025-1.5*IR)

Figure 7. Boxplots of water-quality parameters measured along vertical profiles on the Ohio River between Markland Locks and Dam and McAlpine Locks and Dam during survey 1 (October 27-November 4, 2016) and survey 2 (June 26-29, 2017). 
The data presented in figures 6 and 7 came from the vertical profiles, which was just one of the data-collection methods used. Water-quality data were also collected along cross sections and longitudinal profiles with a towed sonde near the water surface. Summary statistics of water-quality parameters computed from the near-surface measurements along cross sections and longitudinal profiles for each survey are shown in table 1. Similar to the findings for the data from the vertical profiles, the variability of water-quality measurements in the horizontal direction (streamwise and lateral) was also low, as indicated by the small values for the standard deviation.

Although the data indicate the Ohio River water is wellmixed, there were a few vertical locations where different water-quality signatures were detected. Some of these were near the discharge point of a power-generating station along the river, and the rest were at and downstream from the confluence with the Kentucky River. Initial observations during the surveys indicated that streamflow from the Kentucky River could be distinguished from the Ohio River water based on several water-quality parameters, including specific conductance and water temperature. Under certain conditions, streamflow from the Kentucky River entering the Ohio River tends to hug the left bank for several miles downstream and is not immediately mixed with the Ohio River water. A complete analysis of the velocity and water-quality data are beyond the scope of this report, but the supporting data for this and other observations are available for download through the aforementioned data release (Boldt, 2021).

\section{Real-Time Water-Quality Data at Markland Dam}

A water-quality sonde at Markland Dam is in operation seasonally from March through October of each year (U.S. Geological Survey, 2019a). The water-quality sonde is located on the downstream side of the dam near the hydropower station, which is on the right bank or Indiana side of the river, and it currently (2020) provides data at 5-minute increments. Although this water-quality sonde provides measurements at a single, fixed location, the field data from the 2016-2017 surveys showed that the Ohio River is well-mixed at most locations. These readings are therefore assumed to be representative of the reach from Markland Dam to McAlpine Dam. Monthly mean values of selected water-quality parameters from the USGS streamgage Ohio River at Markland Dam near Warsaw, Kentucky (station number 03277200) are shown in table 2 for the period 2011-2020. Although survey 1 and survey 2 were conducted at different times of the year, they do not fully capture the changes in water quality throughout the year, so the data in table 2 provide that longerterm context. Water temperatures during the 2016-2017 calendar years varied seasonally (fig. 8). The maximum water temperature recorded during the 2016 and 2017 calendar years was $29.5^{\circ} \mathrm{C}$ and $28^{\circ} \mathrm{C}$, respectively. The range of water temperatures measured in the Ohio River supports the water temperature range used in the FluEgg model.

Table 1. Summary statistics of water-quality parameters computed from near-surface measurements along cross sections and longitudinals on the Ohio River from Markland Locks and Dam to McAlpine Locks and Dam during survey 1 (October 27-November 4, 2016) and survey 2 (June 26-29, 2017) (fig. 1). Data summarized from Boldt (2021).

$\left[{ }^{\circ} \mathrm{C}\right.$, degrees Celsius; $\mu \mathrm{S} / \mathrm{cm}$, microsiemens per centimeter at 25 degrees Celsius; $\mathrm{mg} / \mathrm{L}$, milligrams per liter; FNU, formazin nephelometric units; RFU, relative fluorescence units; - , no measurement]

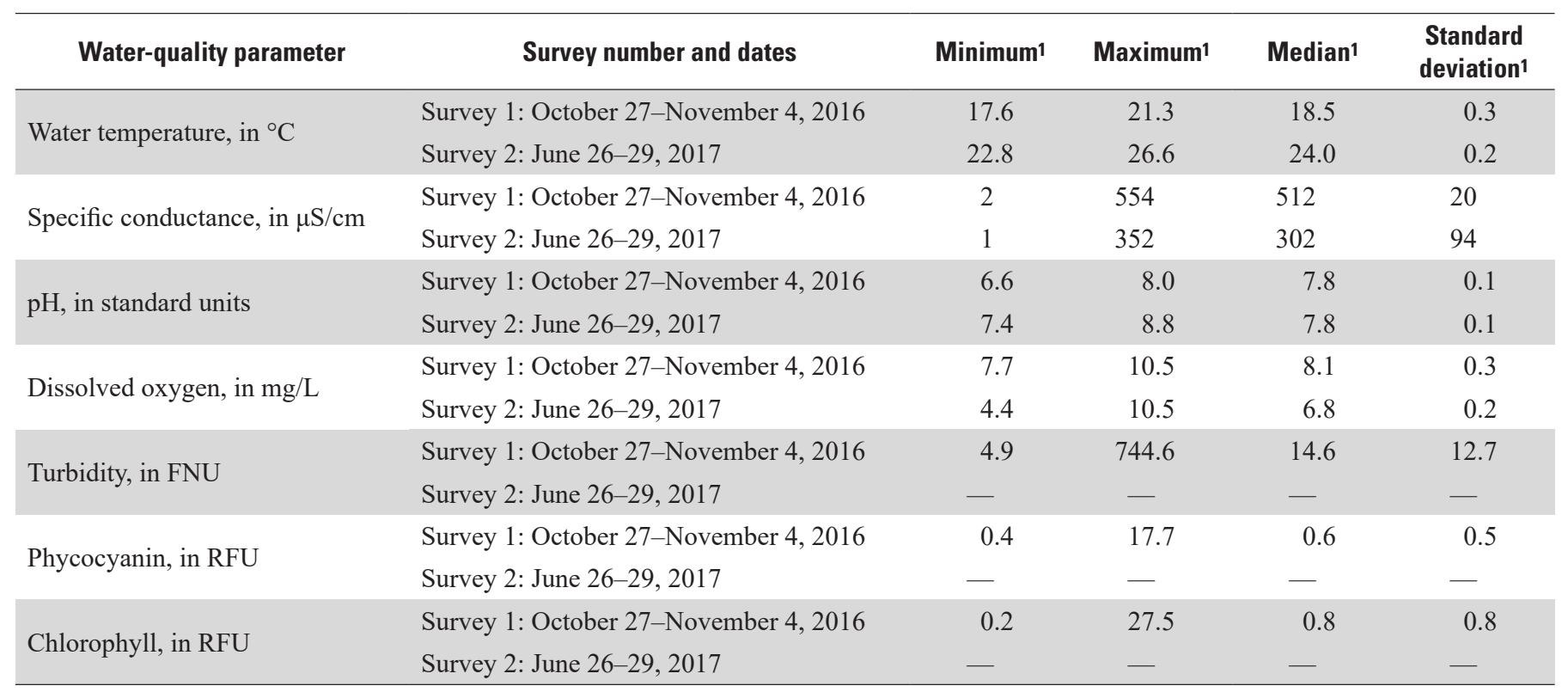

${ }^{1}$ Number of measurements: 4,768 (Survey 1) and 8,542 (Survey 2). 
Table 2. Monthly mean values of selected water-quality parameters from the water-quality sonde at U.S. Geological Survey streamgage Ohio River at Markland Dam near Warsaw, Kentucky (station number 03277200; U.S. Geological Survey, 2019a), 2011-2020.

$\left[{ }^{\circ} \mathrm{C}\right.$, degrees Celsius; $\mu \mathrm{S} / \mathrm{cm}$, microsiemens per centimeter at 25 degrees Celsius; $\mathrm{mg} / \mathrm{L}$, milligrams per liter]

\begin{tabular}{|c|c|c|c|}
\hline Month1,2 & Water temperature ${ }^{\circ}\left({ }^{\circ} \mathrm{C}\right)$ & Specific conductance $^{3}(\mu \mathrm{S} / \mathrm{cm})$ & Dissolved oxygen 3 (mg/L) \\
\hline March & 6.8 & 323 & 11.7 \\
\hline April & 12.5 & 315 & 10.1 \\
\hline May & 18.0 & 309 & 8.5 \\
\hline June & 24.4 & 371 & 7.0 \\
\hline July & 27.0 & 381 & 6.5 \\
\hline August & 27.4 & 410 & 6.3 \\
\hline September & 25.5 & 438 & 5.9 \\
\hline October & 19.5 & 470 & 7.5 \\
\hline
\end{tabular}

${ }^{1}$ Calculation period: March 1, 2011 to May 31, 2020.

${ }^{2}$ The water-quality sonde is in operation from March through October each year.

${ }^{3}$ From the water-quality sonde located on the downstream side of the dam near the hydropower station.

\section{Hydraulic Model}

A copy of the Ohio River Community Model (Adams and others, 2010; hereafter referred to as the Community Model) was obtained in October 2017 from the National Weather Service. The Community Model is a U.S. Army Corps of Engineers' Hydrologic Engineering Center River Analysis System (HEC-RAS) (U.S. Army Corps of Engineers, 2016) step-backwater model (version 5.0) for parts of the Mississippi River and all of the Ohio River including its major tributaries. The Community Model is calibrated and maintained by the National Weather Service and the U.S. Army Corps of Engineers and used independently by both agencies for forecasting and operational purposes. After obtaining a copy of the Community Model, the model was edited to include only the reach (fig. 1) from the Markland Dam to the McAlpine Dam (river miles 531.5 to 606.8, respectively). The edited Community Model contained 122 cross sections covering 70.9 miles $(114.1 \mathrm{~km})$, resulting in a mean spacing between cross sections of approximately $3,100 \mathrm{ft}$.

\section{HEC-RAS Simulations}

Four steady-state step-backwater models were developed using streamflows and water-surface elevations from four measurements made at the Water Tower streamgage (fig. 9). The measurements used were numbers 27, 25, 28, and 23 with streamflows of 11,000 cubic feet per second $(\mathrm{ft} 3 / \mathrm{s})$, $38,100 \mathrm{ft} 3 / \mathrm{s}, 67,600 \mathrm{ft} 3 / \mathrm{s}$, and $108,000 \mathrm{ft} 3 / \mathrm{s}$, respectively (table 3; U.S. Geological Survey, 2019c). The four measurements, made October 2016 to February 2017, were selected to cover a range of conditions, from a high-streamflow event to a seasonal dry-weather streamflow, with two streamflows in-between these extremes (fig. 10). The Water Tower streamgage (established in November 2013) does not have enough historical streamflow data (generally 10 years) to calculate flood-peak statistics using observed streamflow data (Interagency Committee on Water Data, 1982). As an alternative, quantiles of daily mean streamflow (June to September) for the period November 2013 to June 2020 were computed for streamflow comparison purposes (table 4). Measurement $27(11,000 \mathrm{ft} 3 / \mathrm{s})$ approximately corresponds to the 2.5 -percent quantile, and measurement $23(108,000 \mathrm{ft} / \mathrm{s})$ approximately corresponds to the 75-percent quantile.

A second streamgage station, Ohio River upstream of McAlpine Dam at railroad bridge at Louisville, Kentucky (station number 03293551; hereafter referred to as the Railroad streamgage) (U.S. Geological Survey, 2019b), records stage only and is located approximately 4 miles downstream from the Water Tower streamgage (near the upstream end of the McAlpine Dam; fig. 9). Because there is no appreciable tributary input between the two streamgages, the HEC-RAS model runs were started using the stages recorded at the Railroad streamgage (at the same time as the streamflow measurements were made at the Water Tower streamgage) as known water-surface elevations. A comparison of recorded to simulated water-surface elevations at the Water Tower streamgage is given in table 3. Due to uncertainty in tributary inflows, an assumption of constant streamflow along the entire model reach was made for each of the simulated streamflows.

\section{FluEgg Model}

The FluEgg model (Garcia and others, 2013, 2015; Domanski and Berutti, 2020) integrates river hydrodynamics and water temperature with Asian carp egg development and associated physical characteristics to simulate the transport 


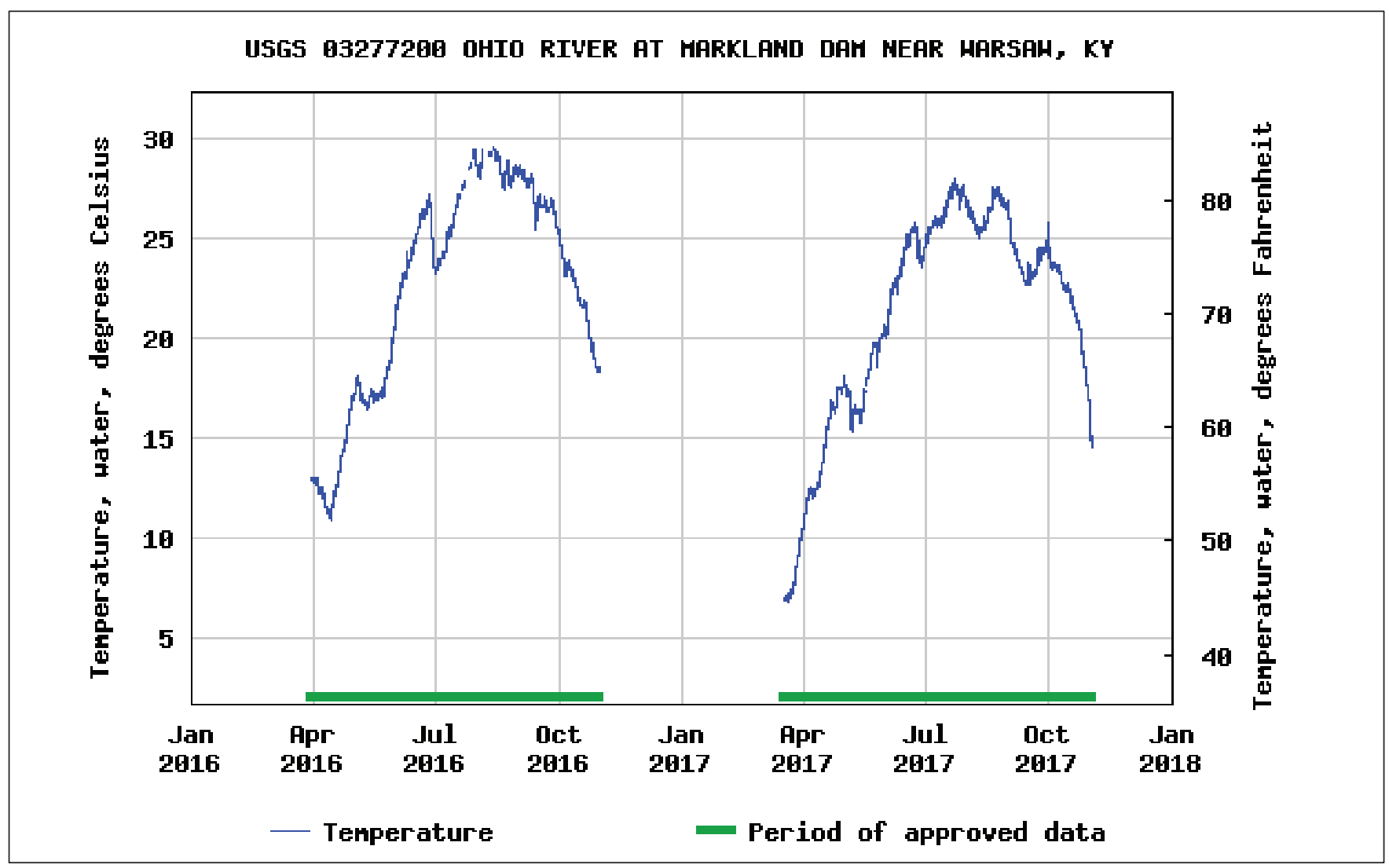

Figure 8. Graph showing water temperature at the U.S. Geological Survey streamgage Ohio River at Markland Dam near Warsaw, Kentucky (station number 03277200; U.S. Geological Survey, 2019a), 2016-2017. These data are from the water-quality sonde located on the downstream side of the dam near the hydropower station.

and dispersal of eggs in a river after spawning. Further detail about the FluEgg model and larval development and movement can be found in Chapman and George (2011), Garcia and others $(2013,2015)$, George and Chapman $(2013,2015)$, Murphy and others (2016), George and others (2017), and Domanski and Berutti (2020). FluEgg version 4.1.0 was used in this study.

\section{FluEgg Model Inputs}

The FluEgg model uses input files that define the hydraulic characteristics of the reach, water temperature, and spawning location to be simulated. A utility program was used to build input files for FluEgg. In addition to allowing user input of water temperatures and spawning locations, the utility program directly read output from the hydraulic model and automatically converted the hydraulic model output data to metric units (needed as FluEgg uses input in metric units). The utility program then built a set of configuration files for use as input to FluEgg. FluEgg was then run in a batch mode for each combination of spawning location, streamflow, and water temperature.

\section{FluEgg Simulations}

A total of 80 simulations were run using the FluEgg model. In each scenario, a total of 5,000 eggs (all assumed to be fertilized and viable) were simulated until the eggs hatched and the larvae reached the gas bladder inflation (GBI) stage. The FluEgg simulations represented the combinations of five water temperatures, four potential spawning locations, and four streamflows (the streamflows used in the HEC-RAS models). The five water temperatures selected $(18,21,24$, 27 , and $30^{\circ} \mathrm{C}$ ) cover the range over which spawning usually occurs (Kolar and others, 2007), and each water temperature was constant throughout the model reach. Table 5 shows the time to egg hatching and GBI stage for bighead carp at various water temperatures (George and Chapman, 2013). Potential spawning locations (fig. 1) were chosen to be in areas of increased turbulence which are critical to spawning (Kolar and others, 2007): (1) the tailwater area downstream from Markland Dam; (2) the turbulent zone downstream from the Ghent Generating Station outfall; (3) the area near the mouth of the Kentucky River; and (4) the turbulent zone downstream 


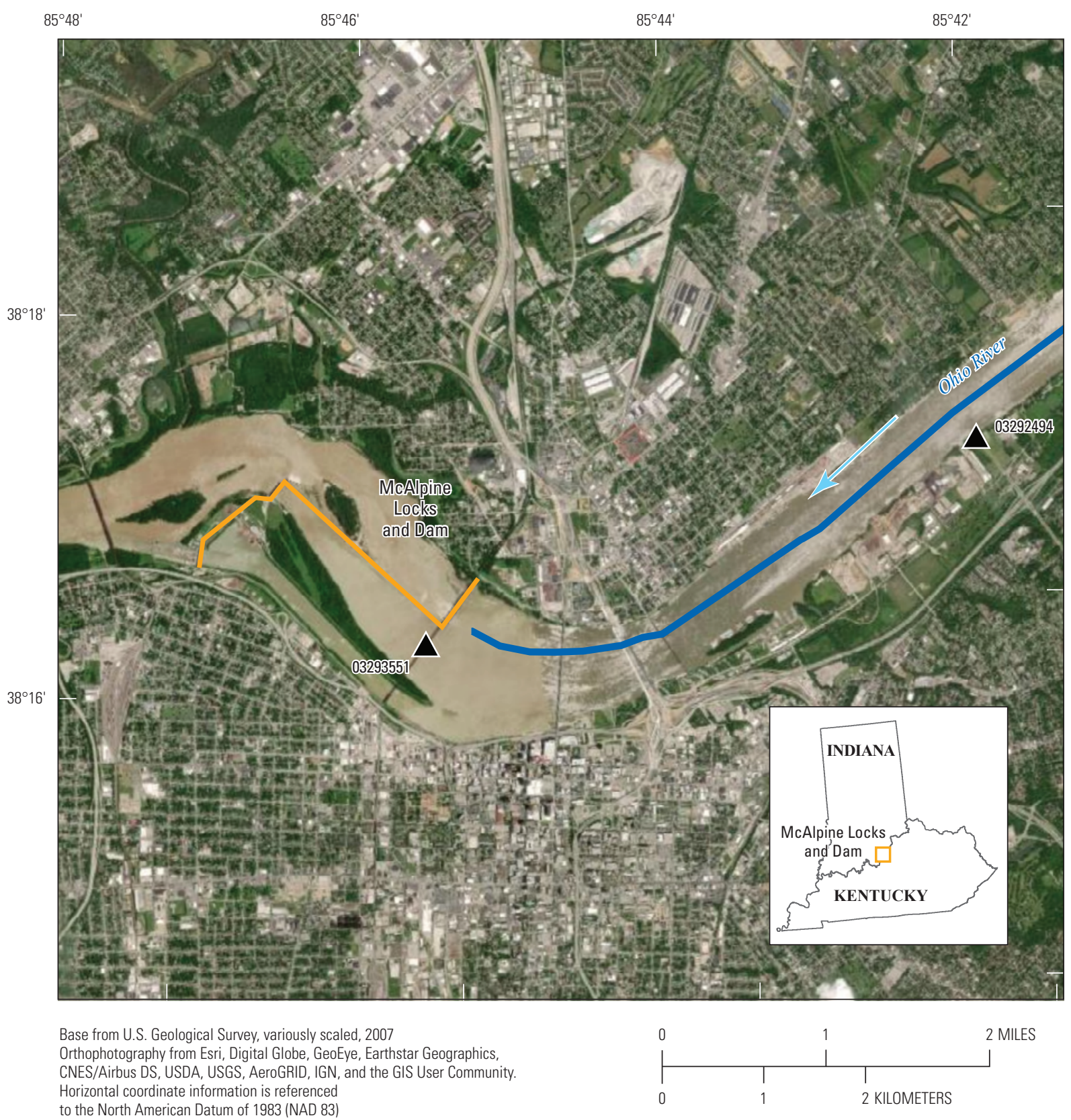

\section{EXPLANATION}

McAlpine Locks and Dam
Study reach
Flow arrow—indicates direction of water flow
U.S. Geological Survey stramgage and number

Figure 9. Map showing locations of the McAlpine Locks and Dam and U.S. Geological Survey streamgages. 
Table 3. Comparison of recorded to simulated water-surface elevations at the U.S. Geological Survey streamgage Ohio River at Water Tower at Louisville, Kentucky (station number 03292494).

[ft3/s, cubic foot per second; ft, foot; NAVD 88, North American Vertical Datum of 1988]

\begin{tabular}{|c|c|c|c|c|c|}
\hline $\begin{array}{l}\text { Measurement } \\
\text { number }\end{array}$ & Streamflow (ftºs) & Recorded stage (ft) & $\begin{array}{l}\text { Recorded water-surface } \\
\text { elevation (ft, NAVD 88) }\end{array}$ & $\begin{array}{l}\text { Simulated water-surface } \\
\text { elevation (ft, NAVD 88) }\end{array}$ & $\begin{array}{l}\text { Difference in } \\
\text { elevation (ft) }\end{array}$ \\
\hline 27 & 11,000 & 12.73 & 419.41 & 419.32 & -0.09 \\
\hline 28 & 67,600 & 12.88 & 419.56 & 419.46 & -0.10 \\
\hline 23 & 108,000 & 12.85 & 419.53 & 419.55 & 0.02 \\
\hline
\end{tabular}

\section{EUSGS}

\section{USGS 03292494 OHIO RIVER AT WATER TOWER AT LOUISVILLE, KY}

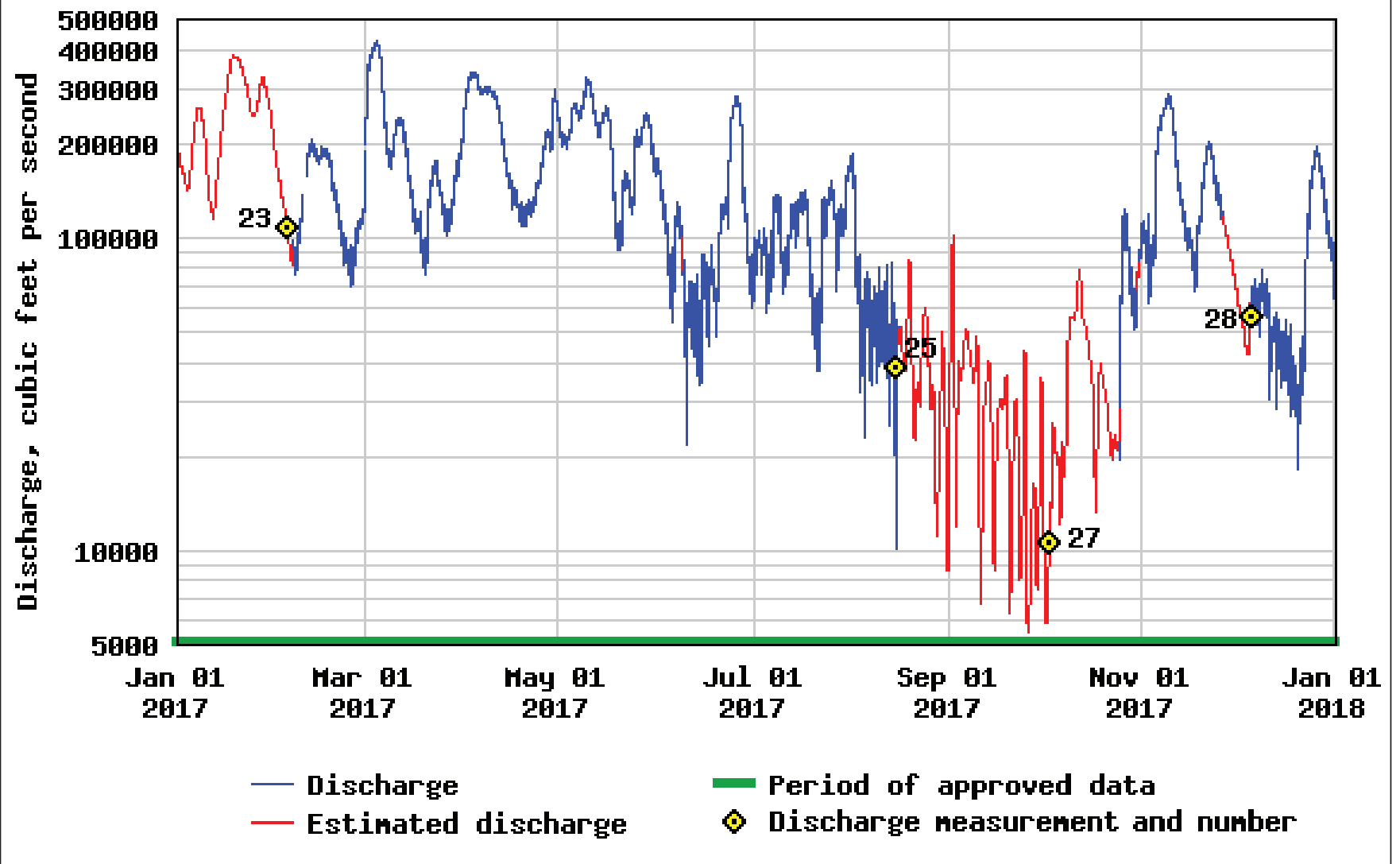

Figure 10. Hydrograph showing the U.S. Geological Survey streamgage Ohio River at Water Tower at Louisville, Kentucky (station number 03292494; U.S. Geological Survey, 2019c), for the period January 1, 2017 to January 1, 2018. 
from the Trimble County Generating Station outfall. For each spawning location, the initial position of the eggs was at a point halfway across the river width and at the water surface.

\section{FluEgg Simulation Results}

The transport of bighead carp eggs from Markland Dam to McAlpine Dam was simulated using the FluEgg model. These simulations provide insight into the transport and dispersion of bighead carp eggs based on varying streamflow and water temperature conditions at four hypothetical spawning locations. The range of simulated streamflow spans a season low-streamflow event to a high-streamflow event, whereas the range of simulated water temperature spans the temperatures when spawning usually occurs (Kolar and others, 2007). Unless otherwise noted, all statements pertain to eggs and larvae within the hydraulic model domain.

Eggs in suspension are considered to be at risk of hatching, whereas eggs near the bottom were considered likely to settle and thus likely to perish (George and Chapman, 2015). Egg mortality was assumed to occur to eggs that were in the bottom 5 percent of the water column at the time of the GBI stage (Garcia and others, 2015). The embryo survival percentage is calculated as the percentage of eggs that survive times the number of larvae that reach the GBI stage divided by the total number of eggs and represents the percentage of embryos that could survive to adulthood and be available for future spawning. As an example, for eggs spawned under all conditions (table 6 ), the egg mortality is 52.5 percent, and the fraction of larvae reaching the GBI stage within the hydraulic model domain is 27.3 percent. The resulting embryo survival percentage is calculated as $(1-0.525) * 0.273=0.130$ or

Table 4. Quantiles of daily mean streamflow for June to September for the period of November 2013 to June 2020 at the U.S. Geological Survey streamgage Ohio River at Water Tower at Louisville, Kentucky (station number 03292494).

[\%, percent; $\mathrm{ft}^{3} / \mathrm{s}$, cubic foot per second]

\begin{tabular}{cc}
\hline Quantile (\%) & Streamflow $(\mathbf{f t} \mathbf{3} / \mathbf{s})$ \\
\hline 100 & 425,000 \\
99.5 & 409,000 \\
97.5 & 333,000 \\
90 & 178,000 \\
75 & 105,000 \\
50 & 56,700 \\
25 & 36,100 \\
10 & 21,300 \\
2.5 & 11,700 \\
0.5 & 7,060 \\
0 & 4,880 \\
\hline
\end{tabular}

13 percent. Summary tables of results are given in tables 6 and 7. For reference, the total study reach is 70.9 miles $(114.1 \mathrm{~km})$ in length.

Table 6 gives an overall summary of combined model results. On average, for all simulations, the FluEgg model predicts that within the hydraulic model domain around 75 percent of all eggs will hatch, about half of the resulting larvae will die, and about a quarter of the surviving larvae will reach the GBI stage. This results in a mean embryo survival rate of 13 percent. Although generalized, the averaged results point to a low chance for an egg spawned between Markland and McAlpine Dams to survive the drifting phase of the life cycle in the intervening pool. This may be due to the generally low velocities within the model reach. The mean reach velocities in the hydraulic model for the simulated streamflows $\left(11,000 \mathrm{ft}^{3} / \mathrm{s}, 38,100 \mathrm{ft}^{3} / \mathrm{s}, 67,600 \mathrm{ft}^{3} / \mathrm{s}\right.$, and $\left.108,000 \mathrm{ft}^{3} / \mathrm{s}\right)$ were $0.26 \mathrm{ft} / \mathrm{s}, 0.87 \mathrm{ft} / \mathrm{s}, 1.46 \mathrm{ft} / \mathrm{s}$, and $2.17 \mathrm{ft} / \mathrm{s}$, respectively.

Looking at the averaged results a little closer, the percentages of eggs that hatch, egg mortality, and larvae reaching the GBI stage all increased with increasing water temperature but were inversely related to streamflow. The increase in egg mortality with increasing water temperature is a result of the egg density remaining constant as the water density decreases with higher water temperatures (resulting in less egg buoyancy). The decrease in egg mortality with increasing streamflow is because higher streamflows result in higher streamwise and shear velocities and reduce the likelihood of egg settling and death.

The embryo survival percentage also increased with water temperature but showed a distinct dropoff at streamflow greater than $38,100 \mathrm{ft} 3 / \mathrm{s}$. Egg hatching success, mortality, larvae reaching the GBI stage, and embryo survival percentages all decreased with increasing downstream spawn

Table 5. Time to egg hatching and gas bladder inflation stages for bighead carp at various water temperatures. Data summarized from George and Chapman (2013).

$\left[{ }^{\circ} \mathrm{C}\right.$, degrees Celsius $]$

\begin{tabular}{ccc}
\hline $\begin{array}{c}\text { Water temperature } \\
\left({ }^{\circ} \mathbf{C}\right)\end{array}$ & $\begin{array}{c}\text { Egg hatching time } \\
\text { (hours) }\end{array}$ & $\begin{array}{c}\text { Gas bladder infla- } \\
\text { tion time (hours) }\end{array}$ \\
\hline 18 & 57.8 & 252.4 \\
21 & 41.1 & 152.8 \\
24 & 30.5 & 109.5 \\
27 & 23.5 & 85.4 \\
30 & 18.6 & 69.9 \\
\hline
\end{tabular}


Table 6. Mean percentages of egg hatching, egg mortality, larvae reaching gas bladder inflation stage, and embryo survival on the Ohio River between Markland Locks and Dam and McAlpine Locks and Dam, determined by use of the Fluvial Egg Drift Simulator. Results summarized from Ostheimer (2021).

[\%; percent; $\mathrm{ft} 3 / \mathrm{s}$, cubic foot per second; ${ }^{\circ} \mathrm{C}$, degrees Celsius; $\mathrm{km}$, kilometer]

\begin{tabular}{|c|c|c|c|c|}
\hline \multirow[b]{2}{*}{ Variable } & \multicolumn{4}{|c|}{ Averages (arithmetic means) within the hydraulic model domain } \\
\hline & Egg hatching (\%) & Egg mortality (\%) & $\begin{array}{c}\text { Larvae reaching gas } \\
\text { bladder inflation stage (\%) }\end{array}$ & Embryo survival (\%) \\
\hline All & 75.1 & 52.5 & 27.3 & 13 \\
\hline \multicolumn{5}{|c|}{ Streamflow $\left(\mathrm{ft}^{3} / \mathrm{s}\right)$} \\
\hline 67,600 & 65.8 & 36.3 & 3.3 & 2.1 \\
\hline 108,000 & 46.6 & 24.7 & 0.3 & 0.2 \\
\hline \multicolumn{5}{|c|}{ Water temperature $\left({ }^{\circ} \mathrm{C}\right)$} \\
\hline 18 & 52.1 & 46.6 & 14.8 & 7.9 \\
\hline 30 & 90.2 & 59.3 & 42.8 & 17.4 \\
\hline \multicolumn{5}{|c|}{ Distance downstream from Markland Locks and Dam (km) } \\
\hline 0 & 90.1 & 57.2 & 37.3 & 15.9 \\
\hline 5.5 & 88.3 & 55.7 & 35.1 & 15.6 \\
\hline 20.9 & 81 & 53.2 & 25.6 & 12 \\
\hline 62.5 & 40.9 & 43.8 & 11.3 & 6.4 \\
\hline
\end{tabular}

location; however, this is likely due to the spawn location's increased proximity to the downstream hydraulic model domain rather than changing hydraulic characteristics within the model reach. Generally speaking, the highest chance for embryo survival occurs during mid to low streamflows and at higher water temperatures, somewhat irrespective of the spawning location.

Table 7 gives detailed model results which can be used to predict the likely extent of an egg plume given the spawn location, water temperature, and streamflow conditions during spawning. As expected, the length of time for the eggs to hatch and for the larvae to reach the GBI stage was inversely related to the water temperature, because warmer water temperatures result in faster egg development (Chapman and George, 2011). Another expected observation was that the egg plume traveled farther downstream for the higher-streamflow events. The combination of low water temperature and high-streamflow events resulted in cases where some of the eggs and larvae passed downstream from the hydraulic model domain (hereafter referred to as outside model domain [OMD] results) before hatching or reaching the GBI stage.

The condition of passing out of the hydraulic model domain was further exacerbated by the proximity of potential spawning locations to the downstream end of the study reach. Although the locations of the OMD eggs and larvae are unknown, these results still provide useful information. The OMD simulations provide clues as to what conditions may result in eggs hatching and/or larvae reaching the GBI stage downstream from McAlpine Dam. A notable OMD simulation occurs for spawning just downstream from Markland Dam during low water temperature $\left(18^{\circ} \mathrm{C}\right)$ and high-streamflow conditions (streamflow of $108,000 \mathrm{ft} 3 / \mathrm{s}$ ), which results in most of the eggs hatching and all larvae reaching the GBI stage downstream from McAlpine Dam (a distance of over 70.9 miles [114.1 km]).

The best chance for bighead carp embryo-larval survival occurs when eggs are spawned at the Ghent Generating Station with a streamflow of $38,100 \mathrm{ft} 3 / \mathrm{s}$ and a water temperature of $30^{\circ} \mathrm{C}$. For this simulation, the embryo survival rate was 41.9 percent. Example maps of quantile locations for both egg hatching and larvae at the GBI stage for this simulation are given in figures 11 and 12, respectively. The same streamflow and water temperature conditions also result in the second highest embryo survival rate (26.7 percent) for eggs spawned just downstream from Markland Dam (figs. 13 and 14). Eggs spawned at a streamflow of $38,100 \mathrm{ft} 3 / \mathrm{s}$ and water temperatures of 24 to $30{ }^{\circ} \mathrm{C}$ tended to have the highest embryo survival percentages. Conversely, embryo survival percentages 
were lowest for both the lowest and highest simulated streamflows regardless of water temperature or spawn location. An example of poor embryo survival (0 percent) is for eggs spawned near the mouth of the Kentucky River at a streamflow of $108,000 \mathrm{ft} 3 / \mathrm{s}$ and a water temperature of $18{ }^{\circ} \mathrm{C}$.

Of the 80 FluEgg simulations, 72 had embryo survival rates of less than 10 percent. Four of the simulations had embryo survival rates between 10 and 20 percent, three more were between 20 and 30 percent, and only one event was greater than 40 percent. Except for eight specific simulations, the chances for bighead carp to establish a self-sustaining population upstream from McAlpine from eggs spawned anywhere downstream from Markland Dam appear to be low. However, if spawning occurs under the right conditions, the chance greatly improves.

In addition to the tabled results, a zipped keyhole markup language $(\mathrm{kmz})$ file was created to facilitate visualization of the simulated scenario results. The kmz file can be used to display geographic information in an Earth browser such as Google Earth, Marble, Merkaartor, and Global Mapper. The datasets used in this study, models, and results are available through a data release at https://doi.org/10.5066/P9JHLGZL (Ostheimer, 2021).

FluEgg simulations of the river reaches upstream from Markland Dam that factor in a more current (2020) understanding of the invasion and reproduction fronts are needed to characterize the possibility that bighead carp originated from spawning in reaches upstream from Markland Dam. FluEgg simulation results indicate scenarios in which all or most of the simulated larvae reach the GBI stage after passing downstream from McAlpine Dam from as far upstream as 70.9 miles (114.1 kilometers). Under those conditions, the spawning origin of bighead carp found downstream from McAlpine Dam would therefore be difficult to ascertain. In these scenarios, bighead carp in the reproduction front downstream from McAlpine Dam may have been spawned downstream from McAlpine Dam, between McAlpine and Markland Dams, or even in a segment of the 2014 invasion front mapped upstream from Markland Dam (Ohio River Fisheries Management Team, 2014).

Varying hydraulic conditions in alternating dam to dam reaches along the Ohio River could affect FluEgg simulations upstream from Markland Dam and affect interpretations of where bighead carp are likely to develop into larvae or GBI stages farther downstream. The low velocities characteristic of much of the Markland Dam to McAlpine Dam reach are not necessarily representative of the Ohio River upstream from Markland Dam. Streambed slope tends to increase with distance upstream within a drainage basin. The lower part of the Ohio River from its mouth to about McAlpine Locks and Dam has a nearly constant slope of about 0.000056 (feet by feet, dimensionless) that increases slightly to 0.000089 upstream to Pittsburgh, Pennsylvania (not shown) in an overall concave upward pattern (Carlston, 1969). Increased streambed slope results in higher streamwise and shear velocities, ultimately making it somewhat less likely for an egg to settle and die. In addition, the relative magnitude and frequency of tributary inputs that include areas of increased turbulence critical to spawning (Kolar and others, 2007) may be different upstream from Markland Dam leading to increased spawning opportunities.

The Ohio River Basin Asian Carp Control Strategy Framework (Ohio River Fisheries Management Team, 2014) identified individual bighead carp in the Ohio River well upstream from Markland Dam along almost the entire southern border of the State of Ohio. Additional FluEgg simulations and interpretation would be needed to address the likelihood of roaming bighead carp spawning in reaches upstream from Markland Dam, establishing populations in the Ohio River downstream from McAlpine Dam.

Although these model results are specific to bighead carp, they are generally applicable to silver carp as well. Additional FluEgg simulations would be necessary using model parameters specific to silver carp (George and others, 2017) to obtain results for hatching and GBI stages comparable to those presented for bighead carp.

\section{Limitations}

There are five limitations to consider when interpreting the FluEgg model results. The first four limitations are restated or modified from Murphy and others (2016). The fifth limitation is specific to the Ohio River, for this study, but may apply to other rivers as well.

The first limitation is that egg and larval mortality is based on a simplified principle - eggs are either classified as suspended or near the bottom at hatching time. However, eggs that may have perished because of their proximity to the river bottom at previous time steps are not removed from the simulation. Additionally, under the best of conditions, mortality of eggs and larvae of r-selected (a spawning strategy where large numbers of eggs are produced with little to no parental care afterward) broadcast-spawning fishes such as the bigheaded carps is extremely high due to many factors other than settling, including but not limited to predation or naturally occurring damage to the eggs (such as excess turbulence [Prada and others, 2020]). These are not accounted for in the model. Because all eggs are kept in the simulation, model results for survival are expected to be far higher than the real hatching rate.

The second limitation relates to the water temperature used in the FluEgg simulations because the water temperature was not adjusted to account for diurnal patterns. A typical daytime water temperature was applied to the cells; whereas, the water temperature at a given location varies throughout the day as was shown by the field data collected in this study. The FluEgg model currently (2020) does not account for such fluctuations, which will introduce uncertainty.

A third limitation is that the larval development equations in the FluEgg model are based on limited experimental data. These larval development equations can be refined as 


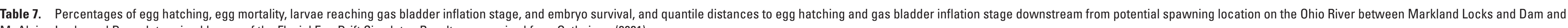
McAlpine Locks and Dam, determined by use of the Fluvial Egg Drift Simulator. Results summarized from Ostheimer (2021).

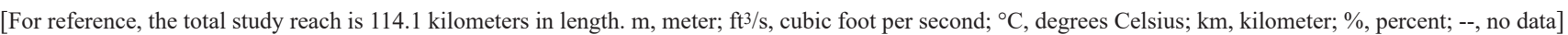

\begin{tabular}{|c|c|c|c|c|c|c|c|c|c|c|c|c|c|c|c|c|c|c|c|c|c|}
\hline \multicolumn{2}{|c|}{ Potential spawning location } & \multirow{3}{*}{$\begin{array}{c}\text { Streamflow } \\
(f \mathbf{t} 3 / \mathbf{s})\end{array}$} & \multirow{3}{*}{$\begin{array}{l}\text { Water } \\
\text { temperature } \\
\text { (ㄷ) }\end{array}$} & \multicolumn{9}{|c|}{ Egg hatching } & \multicolumn{8}{|c|}{ Larval gas bladder inflation stage } & \multirow{3}{*}{$\begin{array}{l}\text { Embryo } \\
\text { survival }(\%)\end{array}$} \\
\hline \multirow[t]{2}{*}{ Location } & \multirow{2}{*}{$\begin{array}{l}\text { Distance downstream } \\
\text { from Markland Locks } \\
\text { and Dam (m) }\end{array}$} & & & \multicolumn{7}{|c|}{$\begin{array}{l}\text { Quantile distance downstream from } \\
\text { potential spawning location }(\mathrm{km})\end{array}$} & \multirow{2}{*}{$\begin{array}{l}\text { Eggs remaining in } \\
\text { hydraulic model } \\
\text { domain }(\%)\end{array}$} & \multirow[t]{2}{*}{ Egg mortality (\%) } & \multicolumn{7}{|c|}{$\begin{array}{l}\text { Quantile distance downstream from } \\
\text { potential spawning location (km) }\end{array}$} & \multirow{2}{*}{$\begin{array}{l}\text { Larvae remaining in } \\
\text { hydraulic model domain (\%) }\end{array}$} & \\
\hline & & & & 0 & 0.1 & 0.25 & 0.5 & 0.75 & 0.9 & 1 & & & 0 & 0.1 & 0.25 & 0.5 & 0.75 & 0.9 & 1 & & \\
\hline \multirow{20}{*}{ 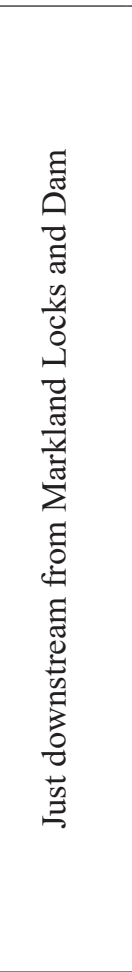 } & \multirow{20}{*}{0} & \multirow{5}{*}{11,000} & 18 & 5.3 & 8.1 & 8.5 & 8.7 & 8.8 & 8.9 & 9.1 & 100 & 99.6 & 20.7 & 50.7 & 66.3 & 81 & 88.3 & 90.9 & 94.7 & 100 & 0.4 \\
\hline & & & 21 & 4.7 & 5.9 & 6.1 & 6.2 & 6.2 & 6.3 & 6.5 & 100 & 97.7 & 7.8 & 33.9 & 39.4 & 42.5 & 43.9 & 44.6 & 46.6 & 100 & 2.3 \\
\hline & & & 24 & 3.8 & 4.6 & 4.7 & 4.8 & 4.8 & 4.8 & 5 & 100 & 99.8 & 6.5 & 25.3 & 27.5 & 29 & 29.8 & 30.3 & 31.7 & 100 & 0.2 \\
\hline & & & 27 & 3.2 & 3.6 & 3.7 & 3.7 & 3.7 & 3.8 & 3.9 & 100 & 99.9 & 8.6 & 20.1 & 21.6 & 22.4 & 22.8 & 23.2 & 24.3 & 100 & 0.1 \\
\hline & & & 30 & 2.7 & 2.9 & 2.9 & 3 & 3 & 3 & 3.1 & 100 & 100 & 8.2 & 16.4 & 17.3 & 18 & 18.4 & 18.7 & 19.5 & 100 & 0 \\
\hline & & \multirow{5}{*}{38,100} & 18 & 13.8 & 38.5 & 45.5 & 50.8 & 53.4 & 54.8 & 57.9 & 100 & 53.3 & 82.1 & -- & $\begin{array}{l}-- \\
\end{array}$ & -- & -- & -- & -- & 0.2 & 0.1 \\
\hline & & & 21 & 12.7 & 28.5 & 32.2 & 34.6 & 35.9 & 36.6 & 38.5 & 100 & 52.5 & 39.6 & -- & -- & -- & -- & -- & -- & 9.4 & 4.5 \\
\hline & & & 24 & 9.2 & 21.8 & 23.2 & 24.3 & 24.9 & 25.3 & 26.7 & 100 & 61 & 28.5 & 76.2 & 107 & -- & -- & -- & -- & 29.5 & 111.5 \\
\hline & & & 27 & 8.5 & 15.8 & 16.9 & 17.6 & 17.9 & 18.3 & 19.5 & 100 & 65.8 & 19.7 & 61.4 & 81.4 & 103.5 & -- & -- & -- & 69.3 & 223.7 \\
\hline & & & 30 & 6.1 & 12.4 & 13 & 13.3 & 13.5 & 13.7 & 14.8 & 100 & 73.3 & 13.6 & 51 & 66.2 & 79.9 & 86.8 & 89.7 & 93.1 & 100 & 226.7 \\
\hline & & & 18 & 24.6 & 64.4 & 85.8 & 111 & -- & -- & -- & 53.8 & 27.5 & -- & -- & -- & -- & -- & -- & -- & 0 & 0 \\
\hline & & & 21 & 15.8 & 49.1 & 61.1 & 72.3 & 78.4 & 81.4 & 86.3 & 100 & 36 & 87 & -- & -- & -- & -- & -- & -- & 0.1 & 0.1 \\
\hline & & 67,600 & 24 & 13 & 38.6 & 44.8 & 49.5 & 51.9 & 53.1 & 56.1 & 100 & 45.7 & 38.6 & -- & -- & -- & -- & -- & -- & 2.9 & 1.6 \\
\hline & & & 27 & 12.5 & 31.4 & 35.2 & 37.6 & 38.7 & 39.4 & 41.5 & 100 & 45.8 & 40.4 & -- & -- & -- & -- & -- & -- & 9.4 & 5.1 \\
\hline & & & 30 & 11.5 & 25 & 27.2 & 28.4 & 29.2 & 29.7 & 31.4 & 100 & 49 & 31.8 & 87.3 & -- & -- & -- & -- & -- & 20.5 & 110.5 \\
\hline & & & 18 & 39.8 & 109.6 & -- & -- & -- & -- & -- & 11.1 & 19.2 & -- & -- & -- & -- & -- & -- & -- & 0 & 0 \\
\hline & & & 21 & 32.4 & 73.4 & 98.8 & -- & -- & -- & -- & 37.3 & 22 & -- & -- & -- & -- & -- & -- & -- & 0 & 0 \\
\hline & & 108,000 & 24 & 21.8 & 57.6 & 72.8 & 90.1 & 97.7 & 102.1 & 109.4 & 100 & 24.7 & -- & -- & -- & -- & -- & -- & -- & 0 & 0 \\
\hline & & & 27 & 17.3 & 45.4 & 57.2 & 65.9 & 70.3 & 72.5 & 76.7 & 100 & 31.7 & 59.8 & -- & -- & -- & -- & -- & -- & 0.6 & 0.4 \\
\hline & & & 30 & 14.3 & 38.6 & 44.3 & 48.7 & 50.8 & 52 & 54.8 & 100 & 40.2 & 57.6 & -- & -- & -- & -- & -- & -- & 3.3 & 2 \\
\hline & & & 18 & 7 & 8.6 & 9 & 9.2 & 9.3 & 9.4 & 9.6 & 100 & 99.8 & 19.3 & 52.8 & 68.7 & 85.6 & 94.4 & 99.6 & 107 & 100 & 0.2 \\
\hline & & & 21 & 4.4 & 6.2 & 6.4 & 6.5 & 6.5 & 6.6 & 6.8 & 100 & 99.2 & 10.8 & 34.9 & 40.7 & 44.5 & 46.4 & 47.3 & 49.6 & 100 & 0.8 \\
\hline & & 11,000 & 24 & 3.8 & 4.6 & 4.7 & 4.8 & 4.8 & 4.9 & 5 & 100 & 99.3 & 9.1 & 26.5 & 29.2 & 31.2 & 32.1 & 32.5 & 33.8 & 100 & 0.7 \\
\hline & & & 27 & 2.9 & 3.5 & 3.6 & 3.6 & 3.7 & 3.7 & 3.8 & 100 & 100 & 9.2 & 21 & 22.3 & 23.3 & 23.9 & 24.3 & 25.3 & 100 & 0 \\
\hline & & & 30 & 2.5 & 2.8 & 2.9 & 2.9 & 3 & 3 & 3.1 & 100 & 99.7 & 9 & 17.5 & 18.5 & 19.1 & 19.5 & 19.8 & 20.5 & 100 & 0.3 \\
\hline & & & 18 & 17.2 & 39.8 & 48.6 & 54.8 & 57.9 & 59.6 & 63.2 & 100 & 50 & 81.4 & -- & -- & -- & -- & -- & -- & 0.1 & 0.1 \\
\hline z & & & 21 & 10.3 & 31.3 & 34.3 & 36.8 & 37.9 & 38.4 & 40.4 & 100 & 57.8 & 44.5 & -- & -- & -- & -- & -- & -- & 6.5 & 2.7 \\
\hline 芯 & & 38,100 & 24 & 11.5 & 22.8 & 25 & 26.1 & 26.8 & 27.2 & 28.7 & 100 & 58.2 & 24.2 & 81.1 & -- & -- & -- & -- & -- & 22.2 & 9.3 \\
\hline $\bar{m}_{b 0}$ & & & 27 & 8.7 & 17.7 & 18.7 & 19.3 & 19.7 & 20 & 20.9 & 100 & 62.4 & 21.4 & 63.6 & 84.4 & -- & -- & -- & -- & 47 & 117.7 \\
\hline 汤 & 5495 & & 30 & 8.7 & 13.3 & 14 & 14.4 & 14.7 & 15 & 16 & 100 & 58.1 & 19.8 & 53.9 & 69.1 & 85.6 & 92.4 & 96.5 & 102.8 & 100 & 341.9 \\
\hline 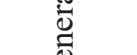 & 5,495 & & 18 & 26.2 & 67.6 & 91.4 & -- & -- & -- & -- & 40 & 28.6 & -- & -- & -- & -- & -- & -- & -- & 0 & 0 \\
\hline$\Xi$ & & & 21 & 20.9 & 50.3 & 63.4 & 77.5 & 84 & 86 & 90 & 100 & 38.9 & 99.2 & -- & -- & -- & -- & -- & -- & 0 & 0 \\
\hline$=$ & & 67,600 & 24 & 16.8 & 38.9 & 47 & 53 & 55.7 & 57 & 60.3 & 100 & 38.5 & 52.7 & -- & -- & -- & -- & -- & -- & 1.6 & 1 \\
\hline & & & 27 & 13 & 32.8 & 36.3 & 38.8 & 40.1 & 40.7 & 42.9 & 100 & 50.3 & 44.3 & -- & -- & -- & -- & -- & -- & 7.2 & 3.6 \\
\hline & & & 30 & 10.6 & 26.4 & 28.7 & 30.5 & 31.4 & 31.9 & 33.3 & 100 & 46.2 & 32 & 92.8 & -- & -- & -- & -- & -- & 15.6 & 8.4 \\
\hline & & & 18 & 47.8 & -- & -- & -- & -- & -- & -- & 7.2 & 19.9 & -- & -- & -- & -- & -- & -- & -- & 0 & 0 \\
\hline & & & 21 & 33.6 & 79.5 & 102.8 & -- & -- & -- & -- & 28.9 & 21.4 & -- & -- & -- & -- & -- & -- & -- & 0 & 0 \\
\hline & & 108,000 & 24 & 18.7 & 58.5 & 78.3 & 94.5 & 103.8 & 108.6 & -- & 90.2 & 21.4 & 90.2 & -- & -- & -- & -- & -- & -- & 0 & 0 \\
\hline & & & 27 & 19.2 & 48.4 & 59.9 & 69.9 & 75.2 & 77.3 & 81.1 & 100 & 28.9 & 54.1 & -- & -- & -- & -- & -- & -- & 0.3 & 0.2 \\
\hline & & & 30 & 16.4 & 39 & 46.7 & 51.9 & 54.4 & 55.5 & 58.6 & 100 & 35.7 & 52.9 & -- & -- & -- & -- & -- & -- & 1.9 & 1.2 \\
\hline
\end{tabular}




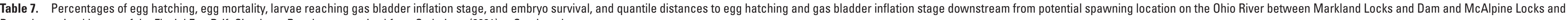
Dam, determined by use of the Fluvial Egg Drift Simulator. Results summarized from Ostheimer (2021).- Continued

\begin{tabular}{|c|c|c|c|c|c|c|c|c|c|c|c|c|c|c|c|c|c|c|c|c|c|}
\hline \multicolumn{2}{|c|}{ Potential spawning location } & \multirow{3}{*}{$\begin{array}{c}\text { Streamflow } \\
(f \mathrm{t} / \mathrm{s})\end{array}$} & \multirow{3}{*}{$\begin{array}{l}\text { Water } \\
\text { temperature } \\
\text { (oC) }\end{array}$} & \multicolumn{9}{|c|}{ Egg hatching } & \multicolumn{8}{|c|}{ Larval gas bladder inflation stage } & \multirow{3}{*}{$\begin{array}{l}\text { Embryo } \\
\text { survival (\%) }\end{array}$} \\
\hline \multirow{2}{*}{ Location } & \multirow{2}{*}{$\begin{array}{l}\text { Distance downstream } \\
\text { from Markland Locks } \\
\text { and Dam }(\mathbf{m})\end{array}$} & & & \multicolumn{7}{|c|}{$\begin{array}{l}\text { Quantile distance downstream from } \\
\text { potential spawning location }(\mathrm{km})\end{array}$} & \multirow{2}{*}{$\begin{array}{l}\text { Eggs remaining in } \\
\text { hydraulic model } \\
\text { domain }(\%)\end{array}$} & \multirow{2}{*}{ Egg mortality (\%) } & \multicolumn{7}{|c|}{$\begin{array}{l}\text { Quantile distance downstream from } \\
\text { potential spawning location }(\mathbf{k m})\end{array}$} & \multirow{2}{*}{$\begin{array}{l}\text { Larvae remaining in } \\
\text { hydraulic model domain }(\%)\end{array}$} & \\
\hline & & & & 0 & 0.1 & 0.25 & 0.5 & 0.75 & 0.9 & 1 & & & 0 & 0.1 & 0.25 & 0.5 & 0.75 & 0.9 & 1 & & \\
\hline \multirow{20}{*}{ 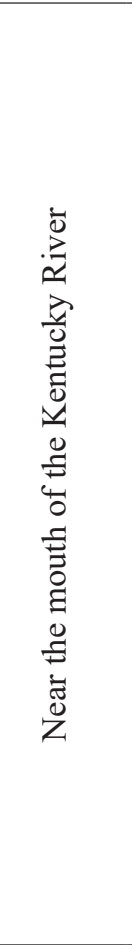 } & \multirow{20}{*}{20,906} & \multirow{5}{*}{11,000} & 18 & 7 & 10.5 & 10.9 & 11.1 & 11.3 & 11.4 & 11.7 & 100 & 98.6 & 16.8 & 57.3 & 81 & -- & -- & -- & -- & 36.1 & 0.5 \\
\hline & & & 21 & 5.5 & 7.2 & 7.5 & 7.6 & 7.7 & 7.8 & 8 & 100 & 98.2 & 17 & 39.8 & 47.5 & 54 & 57.1 & 58.7 & 61.5 & 100 & 1.8 \\
\hline & & & 24 & 4.4 & 5.5 & 5.6 & 5.7 & 5.8 & 5.8 & 6.1 & 100 & 99.9 & 12.7 & 28.8 & 32.7 & 35.6 & 36.9 & 37.6 & 39.3 & 100 & 0.1 \\
\hline & & & 27 & 3.6 & 4.3 & 4.4 & 4.5 & 4.5 & 4.5 & 4.7 & 100 & 99.8 & 10.9 & 23.3 & 25.5 & 26.8 & 27.5 & 27.9 & 29.2 & 100 & 0.2 \\
\hline & & & 30 & 3.1 & 3.4 & 3.5 & 3.5 & 3.6 & 3.6 & 3.7 & 100 & 99.9 & 11.8 & 20.1 & 21.4 & 22.1 & 22.6 & 22.9 & 23.7 & 100 & 0.1 \\
\hline & & \multirow{5}{*}{38,100} & 18 & 22 & 46.4 & 58.4 & 67.9 & 71.4 & 73 & 77.3 & 100 & 46.6 & 91.6 & -- & -- & -- & -- & -- & -- & 0 & 0 \\
\hline & & & 21 & 16.1 & 34.6 & 39.9 & 43.9 & 46.3 & 47.2 & 49.4 & 100 & 48.3 & 46.7 & -- & -- & -- & -- & -- & -- & 1.2 & 0.6 \\
\hline & & & 24 & 11.3 & 26 & 28.7 & 30.5 & 31.5 & 32 & 33.6 & 100 & 50.8 & 30.5 & -- & -- & -- & -- & -- & -- & 9.2 & 4.5 \\
\hline & & & 27 & 12.9 & 20.6 & 22 & 22.9 & 23.3 & 23.7 & 24.8 & 100 & 60.1 & 24.3 & 70.8 & -- & -- & -- & -- & -- & 20.9 & 8.3 \\
\hline & & & 30 & 9.6 & 16.9 & 17.6 & 18.1 & 18.5 & 18.7 & 19.7 & 100 & 61.7 & 17.6 & 60.4 & 81.5 & -- & -- & -- & -- & 37.2 & 114.2 \\
\hline & & & 18 & 24.3 & 78.9 & -- & -- & $\begin{array}{l}-- \\
\end{array}$ & -- & -- & 17.3 & 25.4 & -- & -- & $\begin{array}{l}- \\
\end{array}$ & -- & -- & -- & -- & 0 & 0 \\
\hline & & & 21 & 21.1 & 55.8 & 73.9 & 91.3 & -- & -- & -- & 53.5 & 31 & -- & -- & -- & -- & -- & -- & -- & 0 & 0 \\
\hline & & 67,600 & 24 & 17.6 & 43.8 & 54.9 & 64.3 & 68.4 & 69.5 & 72.4 & 100 & 37.9 & 62.6 & -- & -- & -- & -- & -- & -- & 0.3 & 0.2 \\
\hline & & & 27 & 16.4 & 35.8 & 41.4 & 46.3 & 48.3 & 49.4 & 52.5 & 100 & 40 & 40.1 & -- & -- & -- & -- & -- & -- & 1.8 & 1.1 \\
\hline & & & 30 & 14.7 & 28.9 & 32.3 & 34.6 & 35.8 & 36.4 & 38.5 & 100 & 45.9 & 26.9 & -- & -- & -- & -- & -- & -- & 5.7 & 3.1 \\
\hline & & & 18 & 39.7 & -- & -- & -- & -- & -- & -- & 2.2 & 20.4 & $\begin{array}{l}- \\
\end{array}$ & -- & -- & -- & -- & -- & -- & 0 & 0 \\
\hline & & & 21 & 31.6 & 87.1 & -- & -- & -- & -- & -- & 12.8 & 21.3 & -- & -- & -- & -- & -- & -- & -- & 0 & 0 \\
\hline & & 108,000 & 24 & 26.8 & 64.2 & 86 & 106.6 & -- & -- & -- & 33.8 & 22.5 & -- & -- & -- & -- & -- & -- & -- & 0 & 0 \\
\hline & & & 27 & 17.8 & 51.6 & 66.3 & 78.3 & 85.6 & 87.9 & -- & 100 & 24.4 & 70.1 & -- & -- & -- & -- & -- & -- & 0.1 & 0 \\
\hline & & & 30 & 17.2 & 42.7 & 53.2 & 61.4 & 64.8 & 66.2 & 68.9 & 100 & 31.1 & 60.5 & -- & -- & -- & -- & -- & -- & 0.4 & 0.3 \\
\hline & & & 18 & 10.1 & 19.8 & 21.3 & 22.4 & 22.9 & 23.1 & 24 & 100 & 79.7 & 35 & -- & -- & -- & -- & -- & -- & 0.5 & 0.1 \\
\hline & & & 21 & 9 & 13.9 & 14.7 & 15.2 & 15.4 & 15.6 & 16.2 & 100 & 85.5 & 16.3 & -- & -- & -- & -- & -- & -- & 5.5 & 0.8 \\
\hline & & 11,000 & 24 & 7.6 & 10.4 & 10.8 & 11 & 11.1 & 11.3 & 11.7 & 100 & 91.6 & 17.3 & 45.8 & -- & -- & -- & -- & -- & 20.4 & 1.7 \\
\hline & & & 27 & 5.9 & 8 & 8.5 & 8.7 & 8.8 & 8.9 & 9.1 & 100 & 78.9 & 13.9 & 36.8 & 43.9 & 46.5 & 48.8 & 49.8 & -- & 100 & 221.1 \\
\hline & & & 30 & 5.2 & 6.4 & 6.6 & 6.7 & 6.7 & 6.8 & 7 & 100 & 96.6 & 9.2 & 30.4 & 33.5 & 35.5 & 36.8 & 37.5 & 39.3 & 100 & 3.4 \\
\hline 莺 & & & 18 & 25 & -- & -- & -- & -- & - & -- & 2.3 & 32.8 & -- & -- & -- & -- & -- & -- & -- & 0 & 0 \\
\hline 焉 & & & 21 & 15.9 & 51.3 & -- & -- & -- & -- & -- & 10.3 & 35.9 & -- & -- & -- & -- & -- & -- & -- & 0 & 0 \\
\hline$\stackrel{00}{\Xi}$ & & 38,100 & 24 & 16.2 & 42.1 & 46.5 & -- & -- & -- & -- & 43.3 & 36.3 & -- & -- & -- & -- & -- & -- & -- & 0 & 0 \\
\hline 䓵 & & & 27 & 17.1 & 31.8 & 34.9 & 37.7 & 39.1 & 39.9 & 42.1 & 100 & 38.1 & 39.9 & -- & -- & -- & -- & -- & -- & 0.1 & 0.1 \\
\hline ड్ & 62.503 & & 30 & 12.2 & 26.3 & 28.2 & 29.1 & 29.5 & 29.8 & 30.7 & 100 & 52.3 & 36.6 & -- & -- & -- & -- & -- & -- & 0.4 & 0.2 \\
\hline 2 & 02,303 & & 18 & -- & -- & -- & -- & -- & -- & -- & 0 & 23.8 & -- & -- & -- & -- & -- & -- & -- & 0 & 0 \\
\hline$\overline{\bar{\sigma}}$ & & & 21 & 34.6 & -- & -- & -- & -- & -- & -- & 0.6 & 24.9 & -- & -- & -- & -- & -- & -- & -- & 0 & 0 \\
\hline$J_{0}$ & & 67,600 & 24 & 20.6 & -- & -- & -- & -- & -- & -- & 3.7 & 27.3 & -- & -- & -- & -- & -- & -- & -- & 0 & 0 \\
\hline है & & & 27 & 15 & 49.5 & -- & -- & -- & -- & -- & 11.7 & 30.2 & -- & -- & -- & -- & -- & -- & -- & 0 & 0 \\
\hline & & & 30 & 19.6 & 43.5 & 48.1 & -- & -- & -- & -- & 35.9 & 33.5 & -- & -- & -- & -- & -- & -- & -- & 0 & 0 \\
\hline & & & 18 & -- & -- & -- & -- & -- & -- & -- & 0 & 20.4 & -- & -- & -- & -- & -- & -- & -- & 0 & 0 \\
\hline & & & 21 & 33.2 & -- & -- & -- & -- & -- & -- & 0.1 & 19.8 & -- & -- & -- & -- & -- & -- & -- & 0 & 0 \\
\hline & & 108,000 & 24 & 33.9 & -- & -- & -- & -- & -- & -- & 0.5 & 20.1 & -- & -- & -- & -- & -- & -- & -- & 0 & 0 \\
\hline & & & 27 & 25.6 & -- & -- & -- & -- & -- & -- & 2.1 & 22.8 & -- & -- & -- & -- & -- & -- & -- & 0 & 0 \\
\hline & & & 30 & 21.6 & -- & -- & -- & -- & -- & -- & 6.6 & 25.5 & -- & -- & -- & -- & -- & -- & -- & 0 & 0 \\
\hline
\end{tabular}




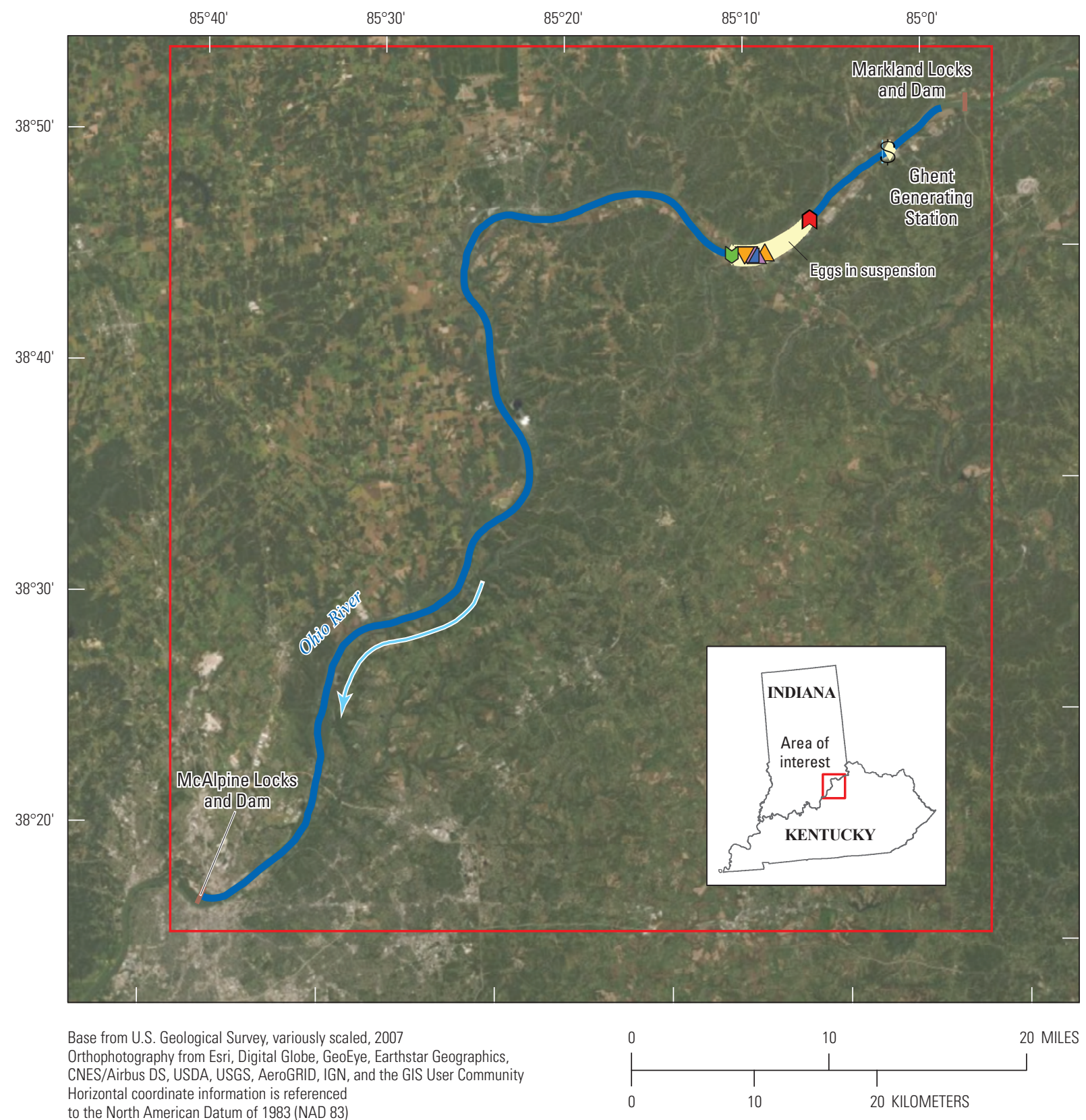

to the North American Datum of 1983 (NAD 83 )

\section{EXPLANATION}

\begin{tabular}{|c|c|c|c|c|c|}
\hline & \multirow[t]{2}{*}{ Area of interest } & I & Dam location & $\triangle$ & 0.25 quantile of egg plume \\
\hline & & $\$$ & Simulated spawn location & 口 & Mean of egg plume \\
\hline & Study reach & $\nabla$ & Eggs in suspension & $\nabla$ & 0.75 quantile of egg plume \\
\hline \multirow[t]{2}{*}{$\leftarrow$} & \multirow{2}{*}{$\begin{array}{l}\text { Flow arrow-indicates } \\
\text { direction of } \\
\text { water flow }\end{array}$} & ఏ & $\begin{array}{l}\text { Trailing edge of egg plume } \\
\text { at hatching time }\end{array}$ & $\nabla$ & 0.9 quantile of egg plume \\
\hline & & $\triangle$ & 0.1 quantile of egg plume & U & $\begin{array}{l}\text { Leading edge of egg plum } \\
\text { at hatching time }\end{array}$ \\
\hline
\end{tabular}

Figure 11. Map showing a simulated suspended egg plume at hatching time for eggs spawned at the outflow of the Ghent Generating Station on the Ohio River at a streamflow of 38,100 cubic feet per second and a water temperature of 30 degrees Celsius. 


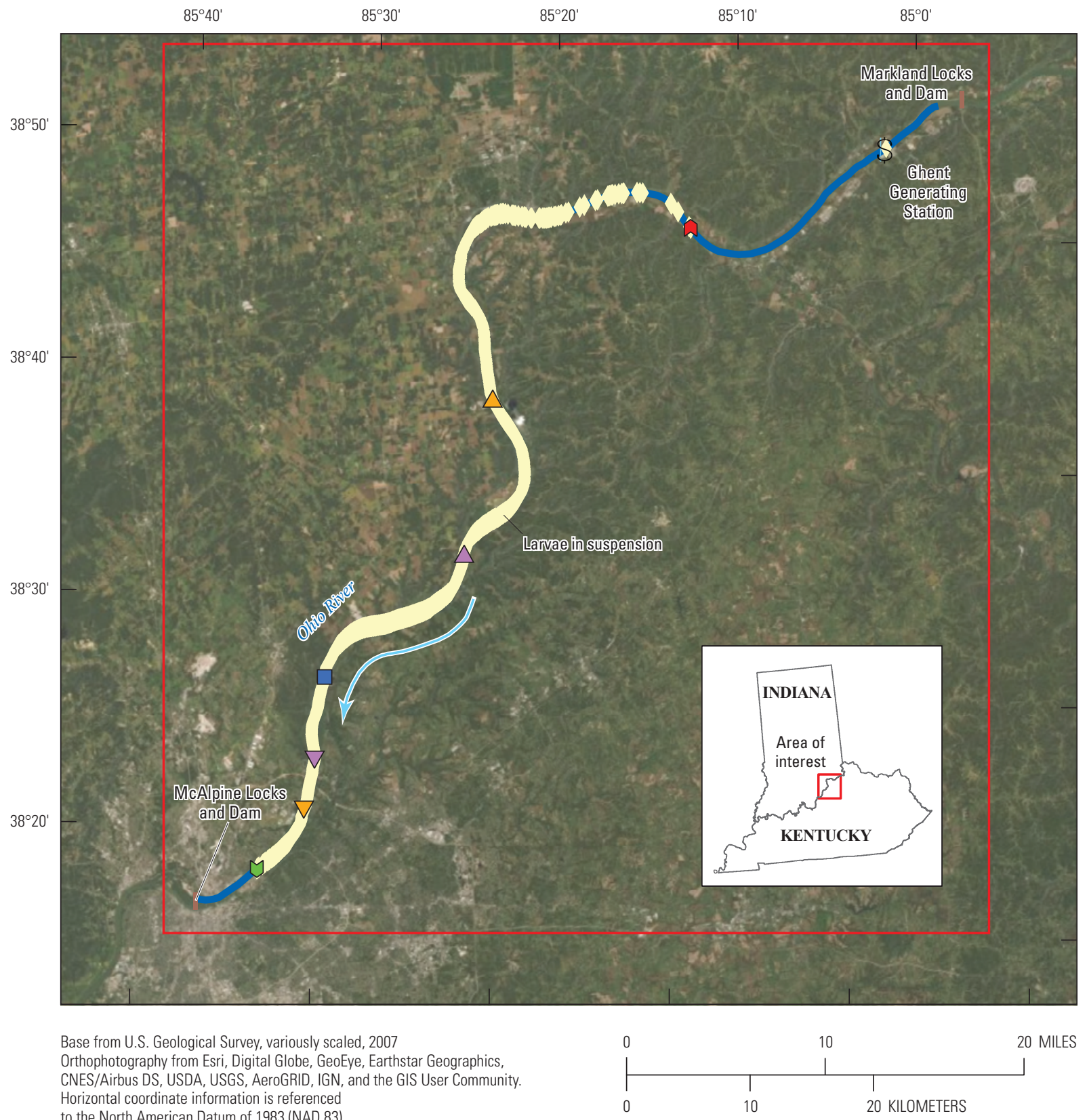

to the North American Datum of 1983 (NAD 83 )

\section{EXPLANATION}

\begin{tabular}{|c|c|c|c|c|c|}
\hline & \multirow[t]{2}{*}{ Area of interest } & 1 & Dam location & $\triangle$ & 0.25 quantile of larval plume \\
\hline & & $\$$ & Simulated spawn location & $\square$ & Mean of larval plume \\
\hline & Study reach & $\nabla$ & Larvae in suspension & V & 0.75 quantile of larval plume \\
\hline \multirow[t]{2}{*}{$\leftarrow$} & $\begin{array}{l}\text { Flow arrow-indicates } \\
\text { direction of } \\
\text { water flow }\end{array}$ & Q & $\begin{array}{l}\text { Trailing edge of larval plume } \\
\text { at gas bladder } \\
\text { inflation time }\end{array}$ & $\nabla$ & 0.9 quantile of larval plume \\
\hline & & & 0.1 quantile of larval plume & & $\begin{array}{l}\text { Leading edge of larval plume at } \\
\text { gas bladder inflation time }\end{array}$ \\
\hline
\end{tabular}

Figure 12. Map showing a simulated suspended larvae plume at gas bladder inflation time for eggs spawned at the outflow from the Ghent Generating Station on the Ohio River at a streamflow of 38,100 cubic feet per second and a water temperature of 30 degrees Celsius. 


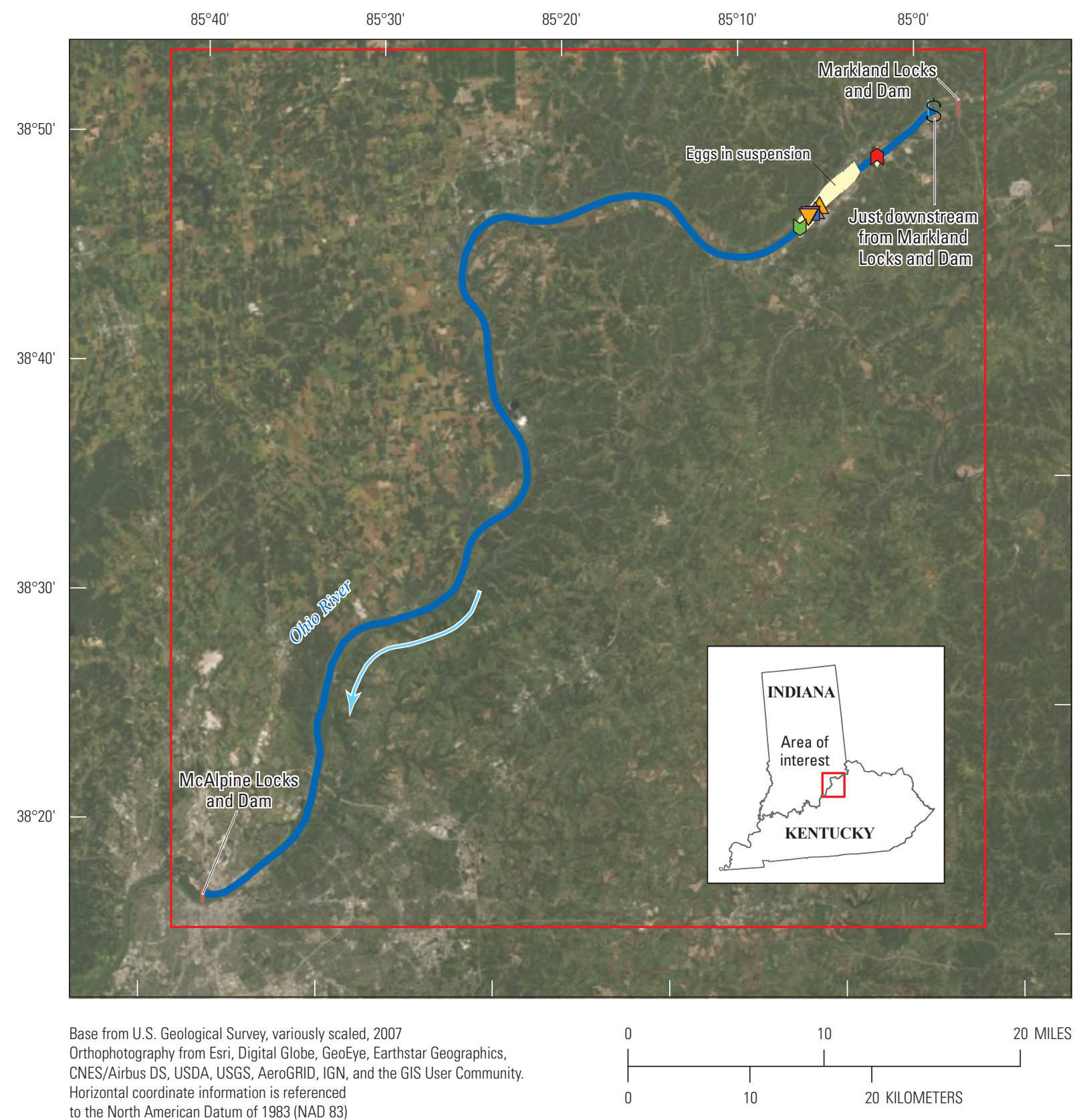

to the North American Datum of 1983 (NAD 83)

\section{EXPLANATION}

\begin{tabular}{|c|c|c|c|c|c|}
\hline & \multirow[t]{2}{*}{ Area of interest } & I & Dam location & $\triangle$ & 0.25 quantile of egg plume \\
\hline & & $\$$ & Simulated spawn location & $\square$ & Mean of egg plume \\
\hline & Study reach & $\diamond$ & Eggs in suspension & $\nabla$ & 0.75 quantile of egg plume \\
\hline \multirow[t]{2}{*}{$\leftarrow$} & \multirow{2}{*}{$\begin{array}{l}\text { Flow arrow-indicates } \\
\text { direction of } \\
\text { water flow }\end{array}$} & ด & $\begin{array}{l}\text { Trailing edge of egg plume } \\
\text { at hatching time }\end{array}$ & $\nabla$ & 0.9 quantile of egg plume \\
\hline & & $\triangle$ & 0.1 quantile of egg plume & Q & $\begin{array}{l}\text { Leading edge of egg plume } \\
\text { at hatching time }\end{array}$ \\
\hline
\end{tabular}

Figure 13. Map showing a simulated suspended egg plume at hatching time for eggs spawned just downstream from the Markland Locks and Dam on the Ohio River at a streamflow of 38,100 cubic feet per second and a water temperature of 30 degrees Celsius. 


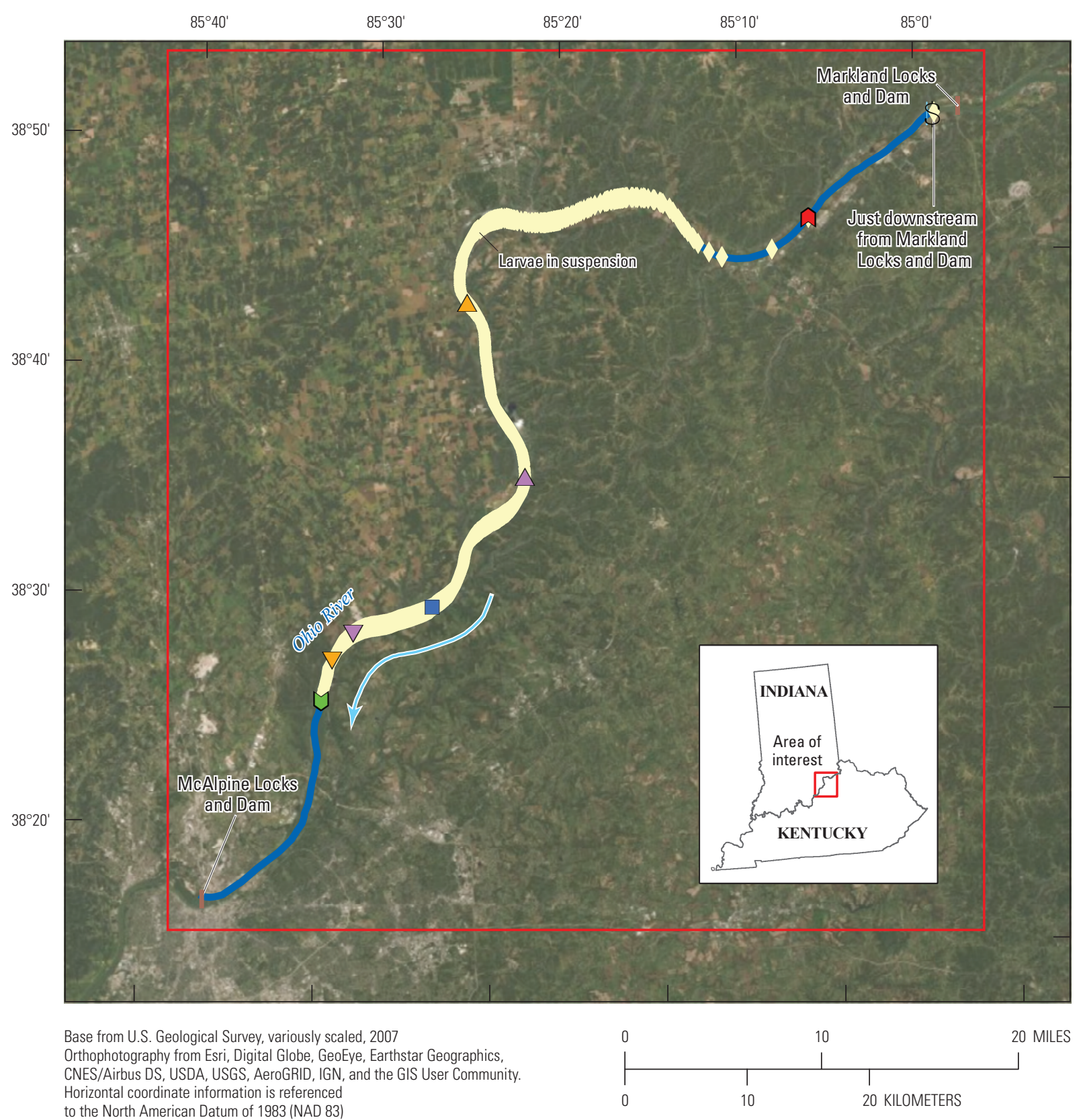

\section{EXPLANATION}

\begin{tabular}{|c|c|c|c|c|c|}
\hline & \multirow[t]{2}{*}{ Area of interest } & I & Dam location & $\triangle$ & 0.25 quantile of larval plume \\
\hline & & $\$$ & Simulated spawn location & $\square$ & Mean of larval plume \\
\hline & Study reach & $\diamond$ & Larvae in suspension & $\nabla$ & 0.75 quantile of larval plume \\
\hline \multirow[t]{2}{*}{$\leftarrow$} & \multirow[t]{2}{*}{$\begin{array}{l}\text { Flow arrow_-indicates } \\
\text { direction of } \\
\text { water flow }\end{array}$} & a & $\begin{array}{l}\text { Trailing edge of larval plume } \\
\text { at gas bladder } \\
\text { inflation time }\end{array}$ & $\nabla$ & 0.9 quantile of larval plume \\
\hline & & $\triangle$ & 0.1 quantile of larval plume & V & $\begin{array}{l}\text { Leading edge of larval plume at } \\
\text { gas bladder inflation time }\end{array}$ \\
\hline
\end{tabular}

Figure 14. Map showing a simulated suspended larvae plume at gas bladder inflation time for eggs spawned just downstream from the Markland Locks and Dam on the Ohio River at a streamflow of 38,100 cubic feet per second and a water temperature of 30 degrees Celsius. 
data from more experiments meeting the water temperature control criteria become available. It should also be noted that there can be large uncertainty from the time of the larval drift to GBI unless there is high resolution streamflow and water temperature data for an extended river reach. The length of time (typically days) that the larvae need to develop to the GBI stage means that they are potentially covering a long reach of the river (depending on streamflow conditions) and could experience large variations in streamflow and water temperature. If the river conditions are overgeneralized, in terms of streamflow or water temperature, then simulations could yield results that are not a realistic reflection of larval transport and development. Again, the field data collected in this study show examples of such variations over time.

A fourth limitation is that the FluEgg models do not simulate complex streamflows immediately upstream and downstream from structures in the reach, such as locks and dams or power plants. The model input file is constructed such that each cell is given values for streamflow and velocity that represent a reach mean. Local hydraulic features (such as eddies or rollers near structures) are not captured, nor is transport through power plants, both of which could affect mortality rates and the rate of egg and larvae transport downstream.

A fifth limitation is that the water levels along the Ohio River are maintained for shipping and navigational purposes, in a series of pools, by sets of locks and dams. The same water-surface elevation in any pool may be associated with a range of streamflows as a result of the operation (gate adjustments) of the downstream controlling dam. It is assumed that typical dam operations occurred for streamflows associated with this modeling effort. However, different egg hatching and larval development conditions may occur under different dam operations for the same streamflows.

\section{Summary}

The U.S. Geological Survey collected data on water quality, stream velocity, and streamflows, and performed hydraulic analyses and simulations of fluvial egg transport along a 70.9-mile reach of the Ohio River between Markland and McAlpine Locks and Dams in Kentucky and Indiana. Data were collected during two surveys: October 27-November 4, 2016, and June 26-29, 2017. The data were collected to aid in identifying reaches of the Ohio River that may provide spawning and recruitment habitat for Hypophthalmichthys nobilis (bighead carp). The hydraulic and fluvial egg transport modeling provide estimates of bighead carp hatching locations under various scenarios of spawning locations, hydrologic streamflow, and water temperature scenarios.

Results of water-quality measurements during the two surveys indicated that water temperature, a variable used in the Fluvial Egg Drift Simulator (FluEgg) model, was consistent throughout the water column. Thus, the use of a single value for water temperature in the FluEgg model is a reasonable assumption based on the field data. Vertical profiles of other water-quality parameters related to habitat and flow in the surveyed reach, and not in the model, were examined. Specific conductance, $\mathrm{pH}$, and chlorophyll were relatively consistent throughout the water column; whereas, dissolved oxygen, turbidity, and phycocyanin showed differences among the three depth categories (top third, middle third, and bottom third of the water column).

A hydraulic model was obtained from the National Weather Service, adapted to the study reach, and used to simulate four different hydrologic conditions. The conditions cover the range of streamflows associated with dry-weather periods to a high-streamflow event. Results from the hydraulic model along with 5 selected water temperatures and 4 selected spawning locations were used to simulate 80 unique scenarios with the FluEgg model.

On average, for all FluEgg simulations, about threequarters of the eggs will hatch, about half of the resulting larvae will die, and about a quarter of the larvae will reach the gas bladder inflation (GBI) stage within the hydraulic model domain. The mean resulting embryo survival rate (the surviving eggs multiplied by the percent of larvae reaching the GBI stage as a fraction of the total eggs spawned) is 13.1 percent. This indicates that, on average for all simulations, the likelihood for a self-sustaining population upstream from McAlpine Locks and Dam resulting from a spawning event in the McAlpine Locks and Dam pool is fairly low. However, the individual simulations have somewhat varied embryo survival likelihoods. The highest embryo survival rate (41.9 percent) occurred for a spawning event at the Ghent Generating Station with a streamflow of 38,100 cubic feet per second and a water temperature of 30 degrees Celsius. In general, eggs spawned at a streamflow of 38,100 cubic feet per second and water temperatures of 24 to 30 degrees Celsius tended to have the highest embryo survival percentages.

There were numerous simulations where all or some of the eggs or larvae did not hatch or reach the GBI stage within the hydraulic model domain. These results tended to happen during higher streamflows with increased water temperature, further exacerbated by proximity of the spawn location to the downstream hydraulic model domain. Although the simulations cannot predict where the eggs hatch or the larvae reach the GBI stage downstream from the hydraulic model domain, knowing when these situations occur still provides useful information.

FluEgg simulations of the river reaches upstream from Markland Locks and Dam that factor in a more current (2020) understanding of the invasion and reproduction fronts are needed to characterize the possibility that bighead carp originated from spawning in reaches upstream from Markland Locks and Dam. Varying hydraulic conditions in alternating dam to dam reaches along the Ohio River could affect FluEgg simulations upstream from Markland Locks and Dam and affect interpretations of where bighead carp are likely to develop into larvae or GBI stages farther 
downstream. Additional simulations and interpretation would be needed to address the likelihood of individual bighead carp spawning in reaches upstream from Markland Locks and Dam, establishing populations in the Ohio River below McAlpine Locks and Dam.

\section{Acknowledgments}

The authors acknowledge the Biological Threats and Invasive Species Research Program of the U.S. Geological Survey Ecosystems Mission Area for providing funding for this study. Thanks to our U.S. Geological Survey colleagues Marian Domanski for assistance with the Fluvial Egg Drift Simulator code and Ryan Jackson for many good discussions about this study.

\section{References Cited}

Adams, T., Chen, S., Davis, R., Schade, T., and Lee, D., 2010, The Ohio River Community HEC-RAS Model: World Environmental and Water Resources Congress 2010. [Also available at https://doi.org/10.1061/41114(371)160.]

Bagnold, R.A, 1966, An approach to the sediment transport problem from general physics: U.S. Geological Survey Professional Paper 422-I, 37 p., accessed July 14, 2020, at https://doi.org/10.3133/pp422I.

Boldt, J.A., 2021, Velocity and water-quality surveys in the Ohio River between Markland Locks and Dam and McAlpine Locks and Dam, Kentucky and Indiana, October 27 November 4, 2016, and June 26-29, 2017: U.S. Geological Survey data release, https://doi.org/10.5066/P9MQHEPU.

Carlston, C.W., 1969, Longitudinal slope characteristics of rivers of the Midcontinent and the Atlantic East Gulf slopes: International Association of Scientific Hydrology Bulletin, v. 14, no. 4, p. 21-31, accessed July 14, 2020, at https://www.tandfonline.com/doi/pdf/10.1080/ 02626666909493751 .

Chapman, D.C., 2010, Facts about invasive bighead and silver carps: U.S. Geological Survey Fact Sheet 2010-3033, 2 p. [Also available at https://doi.org/10.3133/fs20103033.]

Chapman, D.C., and George, A.E., 2011, Developmental rate and behavior of early life stages of bighead carp and silver carp: U.S. Geological Survey Scientific Investigations Report 2011-5076, 11 p. [Also available at https://doi.org/ 10.3133/sir20115076.]

Domanski, M.M., and Berutti, M.C., 2020, FluEgg: U.S. Geological Survey software release, accessed July 14, 2020, at https://doi.org/10.5066/P93UCQR2.
Garcia, M.H., 2008, Sedimentation engineering_-Processes, measurements, modeling and practice, in Marcelo Garcia, eds., ASCE manuals and reports on engineering practice, vol. 110, no. 110: American Society Civil Engineering Publications, Reston, Va. [Also available at https://doi.org/ 10.1061/9780784408148.]

Garcia, T., Jackson, P.R., Murphy, E.A., Valocchi, A.J., and Garcia, M.H., 2013, Development of a fluvial egg drift simulator to evaluate the transport and dispersion of Asian carp eggs in rivers: Ecological Modelling, v. 263, p. 211-222. [Also available at https://doi.org/10.1016/ j.ecolmodel.2013.05.005.]

Garcia, T., Murphy, E.A., Jackson, P.R., and Garcia, M.H., 2015, Application of the FluEgg model to predict transport of Asian carp eggs in the Saint Joseph River (Great Lakes Tributary): Journal of Great Lakes Research, v. 41, no. 2, p. 374-386. [Also available at https://doi.org/10.1016/ j.jglr.2015.02.003.]

George, A.E., and Chapman, D.C., 2013, Aspects of embryonic and larval development in bighead carp Hypophthalmichthys nobilis and silver carp Hypophthalmichthys molitrix: PLoS One, v. 8, no. 8. [Also available at https://doi.org/10.1371/journal.pone.0073829.]

George, A.E., and Chapman, D.C., 2015, Embryonic and larval development and early behavior in grass carp, Ctenopharyngodon idella-Implications for recruitment in rivers: PLoS One, v. 10, no. 3, 14 p. [Also available at https://doi.org/10.1371/journal.pone.0119023.]

George, A.E., Garcia, T., and Chapman, D.C., 2017, Comparison of size, terminal fall velocity, and density of bighead carp, silver carp, and grass carp eggs for use in drift modeling, Transactions of the American Fisheries Society, v. 146 , no. 5, 9 p. [Also available at https://doi.org/10.1080/ 00028487.2017.1310136.]

Interagency Committee on Water Data, 1982, Guidelines for determining flood flow frequency: Reston, Va., U.S. Geological Survey Bulletin 17B, 183 p.

Kolar, C.S., Chapman, D.C., Courtenay, W.R., Jr., Housel, C.M., Williams, J.D., and Jennings, D.P., 2007, Bigheaded carps - A biological synopsis and environmental risk assessment: Bethesda, Md., American Fisheries Society Special Publication 33, 204 p.

Mueller, D.S., Wagner, C.R., Rehmel, M.S., Oberg, K.A., and Rainville, F., 2013, Measuring discharge with acoustic Doppler current profilers from a moving boat (ver. 2.0, December 2013): U.S. Geological Survey Techniques and Methods, book 3, chap. A22, 95 p., accessed July 14, 2020, at https://dx.doi.org/10.3133/tm3A22. 
Murphy, E.A., Garcia, T., Jackson, P.R., and Duncker, J.J., 2016, Simulation of hypothetical Asian carp egg and larvae development and transport in the Lockport, Brandon Road, Dresden Island, and Marseilles Pools of the Illinois Waterway by use of the fluvial egg drift simulator (FluEgg) model: U.S. Geological Survey Open File Report 2016-1011, 19 p., accessed July 14, 2020, at https://doi.org/ 10.3133/ofr20161011.

Murphy, E.A., and Jackson, P.R., 2013, Hydraulic and waterquality data collection for the investigation of Great Lakes tributaries for Asian carp spawning and egg-transport suitability: U.S. Geological Survey Scientific Investigations Report 2013-5106, 30 p., accessed August 31, 2020, at https://pubs.usgs.gov/sir/2013/5106.

Ohio River Fisheries Management Team, 2014, Ohio River Basin Asian carp control strategy framework: Ohio River Fisheries Management Team, 17 p, accessed July 14, 2020, at https://www.asiancarp.us/Documents/ORFMT_Asian_ Carp_Strategy.pdf.

Ostheimer, C.J., 2021, Geospatial data and models for the simulation of hypothetical bighead carp egg and larvae development and transport in the Ohio River between Markland Locks and Dam and McAlpine Locks and Dam, Kentucky and Indiana, by use of the Fluvial Egg Drift Simulator: U.S. Geological Survey data release, https://doi. org/10.5066/P9JHLGZL.

Prada, A.F., George, A.E., Stahlschmidt, B.H., Jackson, P.R., Chapman, D.C., and Tinoco, R.O., 2020, Influence of turbulence and in-stream structures on the transport and survival of grass carp eggs and larvae at various developmental stages: Aquatic Sciences, v. 82, no. 16, 16 p., accessed July 14, 2020, at https://doi.org/10.1007/s00027019-0689-1.

Sime, L.C., Ferguson, R.I., and Church, M., 2007, Estimating shear stress from moving boat acoustic Doppler velocity measurements in a large gravel bed river: Water Resources Research, v. 43, no. 3, 12 p.
U.S. Army Corps of Engineers, 2016, HEC-RAS river analysis system-Hydraulic reference manual, version 5.0: Davis, Calif., U.S. Army Corps of Engineers Institute for Water Resources, Hydrologic Engineering Center, [variously paged], accessed August 2, 2019, at https://www.hec.usace.army.mil/software/hec-ras/ documentation/HEC-RAS\%205.0\%20Users\%20 Manual.pdf.

U.S. Geological Survey, 2019a, USGS 03277200 Ohio River at Markland Dam near Warsaw, KY, in USGS water data for the Nation: U.S. Geological Survey National Water Information System database, accessed August 6, 2019, at https://doi.org/10.5066/F7P55KJN [Site information directly accessible at https://waterdata.usgs.gov/ky/nwis/ inventory/?site_no=03277200.]

U.S. Geological Survey, 2019b, USGS 03293551 Ohio R US of McAlpine Dam @ RRB at Louisville, KY, in USGS water data for the Nation: U.S. Geological Survey National Water Information System database, accessed August 6, 2019, at https://doi.org/10.5066/F7P55KJN [Site information directly accessible at https://waterdata.usgs.gov/ky/ nwis/inventory/?site_no=03293551.]

U.S. Geological Survey, 2019c, USGS 03292494 Ohio River at Water Tower at Louisville, KY in USGS water data for the Nation: U.S. Geological Survey National Water Information System database, accessed August 6, 2019, at https://doi.org/10.5066/F7P55KJN [Site information directly accessible at https://waterdata.usgs.gov/ky/nwis/ inventory/?site_no $=03292494$.]

Zhu, Z., Soong, D.T., Garcia, T., Behrouz, M.S., Butler, S.E., Murphy, E.A., Diana, M.J., Duncker, J.J., and Wahl, D.H., 2018, Using reverse-time egg transport analysis for predicting Asian carp spawning grounds in the Illinois River: Ecological Modelling, v. 384, p. 53-62. [Also available at https://doi.org/10.1016/j.ecolmodel.2018.06.003.] 
For additional information contact:

Director, Ohio-Kentucky-Indiana Water Science Center U.S. Geological Survey

6460 Busch Blvd., Suite 100

Columbus, $0 \mathrm{H}$ 43229-1737

Publishing support provided by the

Indianapolis Publishing Service Center 


\section{$\frac{1}{8}$}

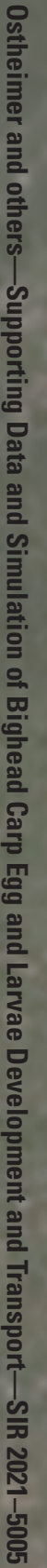

